\title{
PATIENT AUTONOMY AND THE DEFENCE OF MEDICAL NECESSITY: FIVE DUTCH EUTHANASIA CASES
}

\section{BARNEY SNEIDERMAN ${ }^{\circ}$ and MARJA VERHOEF ${ }^{*}$}

In the Netherlands, physicians are allowed to practice euthanasia pursuant to medico-legal guidelines established by the Dutch Supreme Court. The Court has in effect carved out a defence of medical necessity for physicians who would otherwise be convicted of Penal Code offences that are likewise found in the Canadian Criminal Code. The Dutch euthanasia policy, or EAS (euthanasia and assisted suicide), applies to both consensual lethal injection and assisted-suicide scenarios.

The Dutch policy is grounded in the bio-ethical principles of patient autonomy and beneficence. The law stipulates that the request for death must be the voluntary choice of a mentally competent patient whose suffering is unbearable and irremediable. This article discusses the application of these principles in the context of five Dutch EAS cases. The cases illustrate how a commitment to autonomy/beneficence can lead to a broadening of the patient-centred criteria which would justify a physician in taking active steps to end life.
Aux Pays-Bas, les médecins ont le droit de pratiquer l'euthanasie conformément aux directives médico-légales établies par la Cour suprême du pays. La Cour permet en fait aux médecins d'invoquer la défense de nécessité médicale et de se soustraire ainsi à des sanctions du Code pénal semblables à celles du Code criminel canadien. La politique des Pays-Bas en matière d'euthanasie, ou plus précisément d'EAS (euthanasie et aide au suicide), s'applique à la fois à l'injection létale consensuelle et au suicide assisté.

La politique hollandaise se fonde sur les principes bioéthiques de bienfaisance et d'autonomie du patient. La loi stipule que la requête doit exprimer le choix volontaire d'un patient mentalement compétent dont la souffrance est intolérable et irrémédiable. L'article examine l'application de ces principes dans le contexte de cinq cas d'EAS aux Pays-Bas. Ces cas illustrent en quoi l'application du principe de bienfaisance/autonomie peut se prêter à un élargissement du critère axé sur le patient et permettre au médecin d'intervenir activement pour mettre fin à la vie.

\section{TABLE OF CONTENTS}

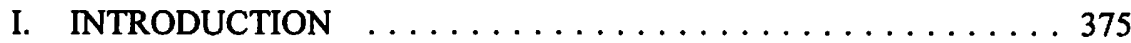

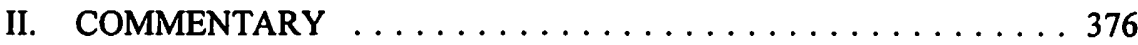

III. HOMICIDE AND THE DEFENCE OF NECESSITY

IN COMMON LAW JURISPRUDENCE . . . . . . . . . 377

IV. ABORTION AND THE DEFENCE OF NECESSITY

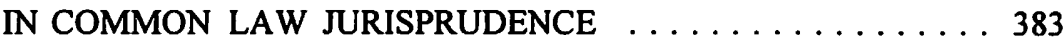

V. EUTHANASIA AND THE EVOLUTION OF THE

DEFENCE OF MEDICAL NECESSITY IN DUTCH LAW . . . . 385

VI. FIVE PIVOTAL DUTCH EUTHANASIA CASES $\ldots \ldots \ldots \ldots 388$

- Professor, Faculty of Law, University of Manitoba.

- Assistant Professor, Department of Community Health Sciences, Faculty of Medicine, University of Calgary.

For their helpful comments on an earlier draft of this paper, the authors would like to acknowledge and thank: Carla Shapiro and David Gregory of the Faculty of Nursing, University of Manitoba; Professor John Griffiths of the Faculty of Law, University of Groningen (the Netherlands); and last, but not least, Attomey Eugene Sutorius of the law firm, Winters and Bosnak Advocaten, Arnhem (the Netherlands). Appreciation is also extended to Alan Katz for discussions of medical issues addressed in the article and to Dutch pharmacist Han Harmsen for providing information about euthanasia and drug dosages. 
A. THE CASE OF DR. SCHOONHEIM

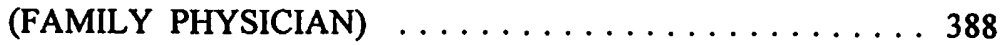

B. THE CASE OF DR. ADMIRAAL (ANAESTHETIST) . . . 392

C. THE CASE OF DR. KORS (PAEDIATRICIAN) . . . . . 393

D. THE CASE OF DR. DUINTJER (PSYCHIATRIST) $\ldots \ldots 396$

E. THE CASE OF DR. CHABOT (PSYCHIATRIST) . . . . . 398

VII. EUTHANASIA IN THE NETHERLANDS:

A MEDICO-LEGAL CONSENSUS $\ldots \ldots \ldots \ldots \ldots \ldots \ldots 406$

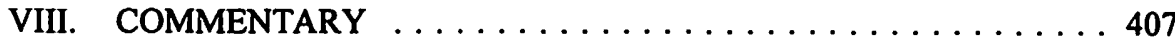

IX. CONCLUSION $\ldots \ldots \ldots \ldots \ldots \ldots \ldots \ldots \ldots \ldots \ldots \ldots 14$

It's not that I'm afraid of dying. I just don't want to be there when it happens.

Woody Allen (b.1935)

\section{INTRODUCTION}

This article will examine the Dutch case law on the defence of medical necessity as applied to a physician who either gives a deliberate lethal injection' to a mentally competent, consenting patient or else assists her or his suicide. In public discourse in Canada and elsewhere, the term "euthanasia" has come to describe these two scenarios; we shall use the term in that double-sided sense. Furthermore, the Dutch euthanasia policy applies to both lethal injection and assisting suicide cases, which explains why Dutch commentators use the acronym EAS (euthanasia and assisted suicide) as a shorthand reference to that policy. Although it is widely believed that euthanasia has been legalized in the Netherlands, that is not the case since the prohibitions in the Penal Code have remained intact. Rather, what has happened is that the Dutch Supreme Court has carved out a defence of necessity whereby physicians are permitted to practice euthanasia in accordance with prescribed guidelines. The applicable Penal Code provisions are as follows (note that there are no mandatory minimum sentences in the Dutch Penal Code):

Article 289 Anyone who deliberately and wilfully takes another person's life is guilty of murder. The maximum sentence is life imprisonment.

Article 293 It is an offence for anyone to take the life of any person at his express and serious request. The maximum sentence is twelve years imprisonment.

Article 294 He who deliberately incites another to commit suicide, assists him to do so, or provides him with the means of doing so, commits an offence if the suicide takes place. The maximum sentence is three years' imprisonment.

Article 40 It is a defence to a criminal charge if the accused was forced by overmacht [circumstances beyond one's control] to commit an offence.

1 The standard procedure in such cases involves two injections: firstly, a barbiturate or anaesthetic to render the patient deeply unconscious; and then the lethal dose - a curare-like (muscleparalysing) drug which causes immediate respiratory arrest. 


\section{COMMENTARY}

In the medical context, article 293 prohibits a physician from compliance with the plea of a mentally competent patient for a lethal injection to end a life of unremitting pain and/or suffering. The provision amounts to the criminalization of so-called Active Voluntary Euthanasia (mercy-killing by request). Still, the consent of the deceased is sufficient mitigation to reduce the killing to a lesser degree of culpable homicide than murder as defined by article 289. That is not the case, however, in common law jurisdictions, where a mercy-killing at the behest of the deceased is categorically defined as murder. For example, the special category of culpable homicide found in article 293 is precluded by section 14 of the Canadian Criminal Code: "[n]o person is entitled to consent to have death inflicted upon him, and such consent does not affect the criminal responsibility of any person by whom death may be inflicted on the person by whom consent is given." 2

The crime of aiding suicide under article 294 is likewise found in common law jurisdictions, although in some American states the act of aiding suicide is defined as either negligent homicide or manslaughter. In Canada, the operative provision is section 241 of the Criminal Code, which prohibits the aiding of suicide (or attempted suicide in the event of failure) and carries a maximum sentence of fourteen years' imprisonment. In contrast, article 294 is triggered only if the person aided actually commits suicide.

According to Dutch case law, the defence of overmacht envisions a case of urgency in which the accused is driven by his conscience to commit an offence which amounts to a lesser evil than would have ensued had he permitted events to run their course. It is in effect a "back to the wall" defence: the accused makes the deliberate moral choice to break the law because the force of circumstances precludes delaying action. However, the defence is not allowable if there was a reasonably available option whereby the accused could have avoided the commission of the offence. Dutch commentators also refer to the defence as force majeure (which like overmacht translates as overpowering force) and as noodtoestand (an emergency situation). The external agency can be either human-directed or the fell clutch of nature or circumstance.

Overmacht is thus the Dutch analogue to the common law defence of necessity, ${ }^{3}$ which also requires that the accused be driven by the force of circumstances to commit an offence as the only way to prevent a greater harm. As a common law defence, necessity has received its most extensive analysis in the case of $R$. v. Perka, a 1984 decision by the Supreme Court of Canada. Speaking for the Court, Dickson J. (as he then was) stated that the public policy rationale for the defence lay in the recognition that "a liberal and humane criminal law cannot hold people to the strict obedience of 
laws in emergency situations where normal human instincts, whether of selfpreservation or of altruism, overwhelmingly impel disobedience." ${ }^{5}$

The Court was quick to add, however, that the defence must be subject to the following limitations:

(1) The defence fails if there was a "reasonable legal alternative" to the commission of the offence. If there was "a legal way out," it follows that the accused was not impelled to act by the dictates of necessity.

(2) There is a "proportionality" requirement, as the criminal law cannot "excuse the infliction of a greater harm to allow the actor to avert a lesser evil." Hence, "the harm inflicted must be less than the harm sought to be avoided."6

In sum, in the jurisprudence of both Dutch law and the common law, an accused can rely upon the defence of necessity only when he acted in an emergency situation in which: (1) there was no legal option reasonably available; and (2) the harm caused by the offence was outweighed by the harm that would have ensued had he stayed his hand.

\section{HOMICIDE AND THE DEFENCE OF NECESSITY IN COMMON LAW JURISPRUDENCE}

Students of criminal law in the common law setting are familiar with two notorious nineteenth century "lifeboat" cases involving shipwrecked survivors: the 1842 case of United States v. Holmes ${ }^{7}$ and the 1884 English case of The Queen v. Dudley and Stephens. ${ }^{8}$ In Holmes, the Federal Circuit Court rejected the defence of necessity to a charge of manslaughter, stemming from the deaths of sixteen passengers ejected from an overcrowded and leaking lifeboat. (The grand jury had refused to return an indictment for murder against Holmes, a sailor who had helped throw the victims overboard.) In Dudley and Stephens, the two accused had been driven, after eight days without food and twenty-four days with only occasional rain water, to kill the cabin boy and feed upon his remains. The Queen's Bench Division denied the defence of necessity to a charge of murder.

In Holmes, the jury was instructed to disregard the defence of necessity because the accused had directed the crew that the unmarried male passengers were expendable: that they were "not to part man and wife, and not to throw over any woman." The effect of that direction was to strip the accused of his only defence to the charge. Holmes was faulted by the Court on the grounds that, if possible, a fair method of selection must be adopted to decide who lives and who dies; and in the instant case there had been ample time to cast lots. Yet what if there had been no time to cast lots because of 
"instant and overwhelming" peril? The Court posed the question but refrained from answering it. It simply went on to state that "[i]n no other than this [casting lots] or some like way are those having equal rights put upon an equal footing, and in no other way is it possible to guard against partiality and oppression, violence and conflict."9 Although the jury convicted the accused of manslaughter, he received a lenient sentence of only six months' imprisonment.

The American Court's appeal to random selection was rejected by the English Court in Dudley and Stephens. As in Holmes, the Court could have rejected the defence on the facts: there was no casting of lots but rather a decision by the two accused to kill and feed upon the cabin boy, whom they considered expendable because he had been drinking sea water and lay prostrate in agony. But the Court went out of its way to reject the defence of necessity as ever excusing the taking of innocent life. In emphatic terms it scorned selection by lot as a "somewhat strange ground" that "can hardly ... be an authority satisfactory to a court in this country." ${ }^{10}$ The Queen's Bench Division thereupon convicted Dudley and Stephens of the charge of capital murder, albeit coupling the verdict with a strong recommendation to the government to exercise its prerogative of mercy. The death sentences were commuted by the home secretary to six months' imprisonment.

As English legal historian Brian Simpson explains in his delightful book, Cannibalism and the Common Law, ${ }^{11}$ the Court's denial of the defence in the broadest possible terms (with or without the drawing of lots) was its way of expressing abhorrence at the practice of maritime survival cannibalism. Although it was the "custom of the sea" for sailors facing imminent starvation to draw lots to determine who died so that others might live, the Queen's Bench Division was determined to express the public policy that such behaviour was a throwback to a primitive stage of human development and, whatever its practice amongst others, it was doubtless beyond the pale for civilized Englishmen. In an opinion that wallows in purple prose, the Court condemned the custom of the sea as a blasphemous appeal to God to sanction the killing of the innocent. In its view, it is better that all should die from starvation than that some should live by resorting to that barbaric custom of the sea.

Aside from the two 19th century lifeboat cases, the recent Saskatchewan mercykilling trial of Robert Latimer ${ }^{12}$ is the only reported case in a common law jurisdiction in which a charge of murder has been met with a defence of necessity. Even so, the broad reach of the ruling in Dudley and Stephens - that necessity can never under any circumstances excuse killing - can be viewed as a quaint Victorian relic standing at

Supra note 8 at 279 , Coleridge C.J.

A.W.B. Simpson, Cannibalism and Common Law (Chicago: University of Chicago Press, 1984). $R$ v. Latimer, [1995] S.J. No. 402 (C.A.) (QL) [hereinafter Latimer]. The Latimer case is discussed shortly. 
cross-purposes to the "liberal and humane criminal law" that grounds the defence of necessity in late 20th century Canadian jurisprudence. ${ }^{13}$

In any event, even in England that celebrated 1884 case has not settled the issue of necessity and homicide, as illustrated by another disaster at sea that happened a century after Dudley and Stephens stood in the dock. In 1987 an inquest was held in England into the deaths of 250 passengers who perished when a cross-channel car ferry struck a pier and capsized as it was leaving the Belgian port of Zeebrugge. A soldier testified that he and dozens of others were in the water but near a rope ladder leading to safety. However, a man on the ladder (likely petrified by cold and fear) blocked their escape by refusing to move up or down. The soldier repeatedly asked him to move but to no effect, whereupon he instructed someone within arm's reach to push him off the ladder. That happened and the man fell into the water and presumably drowned. The soldier and the others then scrambled up the ladder to safety.

In addressing the jury, the coroner stated that "we need at least to glance in the direction of murder." Yet, he hastened to add that there was no clear proof of the death of the petrified man on the ladder but that, "even if there were, I would suggest to you that killing in [sic] a reasonable act of what is known as self-preservation, but that also includes, in my judgment, the preservation of other lives, such killing is not necessarily murder at all."14

He proceeded to direct the jury that there was no evidence of an unlawful killing. ${ }^{15}$ But even if the death had been proven, the coroner would still have directed the jury that the act was not culpable. In any case, who could quarrel with that judgment? After all, if we were to ascribe blame for the death, then we would be bound to bestow praise if the sunken ferry's passengers had resigned themselves to die because they could not in good conscience act to remove the obstacle to their salvation. The absurdity of such a viewpoint speaks for itself.

On the other hand, there is no direct authority in English law to excuse the killing of a defenceless person as necessary to save the lives of others (assuming that the deceased was not arbitrarily selected as the sacrificial victim). There is, of course, the spectre of Dudley and Stephens that would be invoked against the defence, no matter what the circumstances compelling an accused to act. In that regard, it suffices to call to mind one of the many memorable utterances of Justice Oliver Wendell Holmes, "It is revolting to have no better reason for a rule of law than that so it was laid down in the time of Henry IV. It is still more revolting if the grounds upon which it was laid down have vanished long since...."16

13 Apart from that, the repudiation of the defence, even when there was selection by lot, is merely dictum. As a matter of binding precedent, the case therefore did not set the blanket exclusion that academicians and jurists have accorded it. J.C. Smith, Justification and Excuse in the Criminal Law (The Hamlyn lectures) (London: Stevens \& Sons, 1989) at 74. Ibid.

16 O.W. Holmes, "The Path of the Law" (1897) 10 Harvard L. Rev. 457 at 469. 
The uncertainty of English law aside, it is arguable that because the common law defence of necessity is grounded in the philosophy of utilitarianism (committing a lesser harm to prevent a greater harm), it cannot excuse the deliberate killing of a defenceless person unless the one death is necessary to save others. But what if the person is killed, not to save others, but for her own alleged benefit? Is the killer necessarily precluded from pleading the defence of necessity?

In the recent Saskatchewan mercy-killing trial of Robert Latimer, the judge refused to leave the defence of necessity with the jury. A forty-one year old farmer, Latimer faced a charge of first degree murder for the planned and deliberate killing of his twelve year old daughter Tracy by carbon monoxide poisoning. He had vented exhaust fumes from his pickup truck's tail pipe into the cab where he had placed Tracy, a "totally body-involved spastic quadriplegic." She had been gravely effected at birth by cerebral palsy, and constant muscle spasms and seizures had wrenched her body into a twisted frozen position. Tracy was in constant pain from a dislocated hip, and her father was appalled at the prospect of a scheduled, third surgical procedure upon her grossly contorted body (with additional mutilative surgery lying in the future). As he told the police, "My priority was to put her out of her pain." Tracy had the mind of a three-month old baby, weighed thirty-eight pounds, wore diapers, and could not walk, talk or feed herself. Her life was spent either in bed or in a wheelchair. There was compelling evidence that the accused was a loving parent committed to his daughter's wellbeing.

In his closing argument, the defence counsel submitted that Latimer was driven to the deed by his daughter's unremitting pain and that "the situation cried out for action." He was in effect pleading the defence of necessity: that circumstances urgently compelled the accused to commit the crime in order to prevent a greater evil - the continued suffering of his daughter. However, the jury was instructed that such a defence was not available to the accused. The trial judge explained:

[W] hile the doctrine of necessity can sometimes operate to excuse criminal misconduct, I must tell you as a matter of law that the doctrine does not apply in this case. The defence of necessity exists only where the perpetrator's decision to break the law is inescapable and unavoidable and necessary to avert some imminent risk of peril. It arises only in cases where there is no option, no other choice. That was not the situation here. There was an option, albeit not a particularly happy one. The option was to persevere in the attempts to make Tracy comfortable in her life, however disagreeable and heartwrenching those attempts might have been. ${ }^{17}$

Latimer was thus stripped of any defence to the charge and consequently was convicted of second degree murder. ${ }^{18} \mathrm{He}$ was sentenced to life imprisonment with no eligibility for parole for ten years, which is the mandatory minimum sentence for that 
offence. ${ }^{19}$ In July 1995 , eight months after the trial, Latimer's conviction was upheld by the Saskatchewan Court of Appeal. In affirming the instruction to the jury to disregard the defence of necessity, the Court held that the facts clearly fell outside the parameters of the Perka criteria:

In this case the appellant's life was not in peril. He was concerned with Tracy's quality of life. The evidence clearly established the bleak future that faced this little girl.

[The case] deals with the deliberate decision to terminate another's life rather than continue with the scheduled medical treatment and care. In such circumstances it is no defence for a parent to say [that] because of a severe handicap, a child's life has such diminished value that the child should not live any longer. It does not advance the interest of the state or society to treat such a child as a person of lesser status or dignity than others.

Furthermore the evidence is clear that the appellant and his family did have an option. If they could no longer bear the burden of caring for Tracy, there was the real prospect of permanent placement in a group home. ${ }^{20}$

The Court's rejection of the defence of necessity was hardly surprising. Recognition of the defence in such a case would establish a legal excuse for the killing of the severely disabled by care-givers pleading that they had acted to put their loved ones out of their misery. That is, after all, a precedent that Canadian courts are not about to countenance. ${ }^{21}$ Latimer promptly sought leave to appeal the ruling to the Supreme Court, and the high Court will likely hear the case. Since there is no disputing Latimer's guilt, his only real hope on appeal is that a majority of the Court will accept the argument of Saskatchewan Chief Justice Bayda that the mandatory ten year sentence is unconstitutional as measured against the facts of his offence. If that were to happen, Latimer would still be sentenced; but the point is that the trial judge would then be allowed to exercise the sentencing discretion that applies to all Criminal Code offences except murder. ${ }^{22}$

Although his act clearly fit the definition of first degree murder (i.e. a planned and deliberate killing) which carries a mandatory minimum sentence of twenty-five years' imprisonment, for whatever reason the trial judge chose to instruct the jury on both first and second degree murder. Supra note 12 at 84-86.

21 Ibid. at 211-12, Bayda C.J. In his separate opinion, Chief Justice Bayda in effect upheld the conviction but dissented on the sentence. He made no reference to the necessity defence because his quarrel lay not with the label applied to the crime; it was, after all, beyond dispute that Latimer had intentionally committed the actus reus of murder. Rather, his quarrel lay with the punishment. In his view, it was unjust to apply the mandatory minimum sentencing provision for murder to an act such as Latimer's, which was prompted by "love, mercy and compassion." He thus concluded that as enforced against Latimer, the mandatory sentence fell within the prohibition against "cruel and unusual" punishment as found in section 12 of the Canadian Charter of Rights and Freedoms, Part I of the Constitution Act 1982 (U.K.), 1982, c. 11.

As we go to press, the media has reported that R.C.M.P. officers had directly questioned prospective jurors about their views on religion, abortion and mercy-killing. That revelation calls into question whether Latimer received a fair trial before an impartial jury, and the Saskatchewan Justice Department has announced that Latimer is therefore entitled to a new trial. A. Mitchell, "Latimer entitled to a new trial" The Globe and Mail (26 October 1995) A2. 
Although Latimer's mandatory sentence has been widely deplored, none of those canvassed by the media expressed the opinion that such a case should result in an acquittal. However, the view has been expressed (by lawyers amongst others) that the case would have been better dealt with by a guilty plea to manslaughter, an offence that carries no mandatory minimum penalty. The case has also revived the debate whether intentional killing on compassionate grounds should be reclassified as manslaughter.

Setting aside the nonconsensual mercy-killing of a disabled person, consider the following hypothetical scenario. A small airplane crash lands in a field and bursts into flames, trapping the pilot. A deer hunter is at the crash site moments later but cannot attempt rescue because of the flames and intense heat. The horrified realization that the struggling pilot is doomed to be roasted alive impels him to an act of compassion and mercy. He aims his rifle at the pilot's head and shoots moments before his body is consumed by the flames. Admittedly, he has committed what amounts to the act of attempted murder (not necessarily murder because it cannot be proven that the gunshot wound caused the death).

Nonetheless, the compelling nature of the act might well prompt the Crown to stay the proceedings. After all, the act of the accused has met the criteria for the defence of necessity: an emergency situation in which the only avenue open to the accused to prevent the greater evil (the victim being burned alive) was to cut short his agony by firing a bullet into his head. Even if prosecuted, one would think it highly unlikely that a jury could ever be convinced to convict.

In theory then, the defence of necessity is not precluded when the accused is charged with what in effect amounts to a mercy-killing, even when (as in our hypothetical case) the deceased did not consent to the act. However, even if the accused is a physician and the deceased a patient who had pleaded for a lethal injection to end a life of unrelenting suffering, the public policy underlying the common law position is that the defence of necessity cannot be allowed to undermine the absolute bar against the mercy-killing of a patient, whether consenting or not. ${ }^{23}$ In fact, although there have been about a dozen mercy-killing cases involving physicians in common law jurisdictions, not one has even raised a necessity defence.

The policy is illustrated by the unreported 1992 English case of $R$. v. Cox, ${ }^{24}$ in which the accused-physician was charged with attempted murder after he gave a lethal dose of potassium chloride to a seventy year old patient who had begged him to end her life. The patient was dying of rheumatoid arthritis, complicated by gastric ulcers, fractured vertebrae, internal bleeding, gangrene and body sores. Massive doses of heroin were unable to relieve her agony because her ravaged body could not absorb them. A nurse reported that "she howled and screamed like a dog" when anyone touched her and

Even though section 14 of the Criminal Code forecloses a defence of consent to a murder charge, it does not specifically rule out a defence of necessity. The scant likelihood that a court would accept that common law defence to a consensual killing is a different matter. 
a hospital chaplain said that he had never seen anyone else "so much eaten by pain." (The reason that Dr. Cox was not charged with murder was that, since the patient was about to expire in any event, the Crown could not prove the medical cause of death.) According to the accused, "I seemed to have no more options left. She was going to die very soon in any case. I was faced with a choice of several evils. I chose what seemed to me the least evil with respect to (the patient) at that time. ${ }^{.125}$

Still, the accused did not seek to excuse his act on the grounds of (medical) necessity. Aside from the spectre of Dudley and Stephens, the time-honoured prohibition against active voluntary euthanasia was apparently sufficient to preclude the defence counsel from presenting a necessity plea. The accused was therefore left with no defence to the charge, and the trial judge accordingly instructed the jury that the evidence of guilt was overwhelming and that it had no option but to convict. The jury complied, although a number of jury members were in tears when the verdict was announced. Dr. Cox received a one year suspended sentence, and although reprimanded by the General Medical Council he was not stricken from the medical rolls.

The defence of necessity was also conspicuously absent in two unreported Ontario mercy-killing cases, $R$. v. Mataya (1992) and $R$. v. de la Rocha (1993). ${ }^{26}$ The former involved a nurse and the latter a physician, each charged with the murder of a patient whose death was imminent and who was suffering grievously (neither act was at the behest of the patient). In each case, the accused, who had administered a lethal dose of potassium chloride, was allowed to plead guilty to the Criminal Code offence of "administer[ing] any ... noxious thing" (section 245) and was not incarcerated.

\section{ABORTION AND THE DEFENCE OF NECESSITY IN COMMON LAW JURISPRUDENCE}

Although excluded from application in euthanasia cases, the judiciary has not adopted a blanket prohibition against the defence of medical necessity when a physician stands accused of a criminal act. In $R$. v. Bourne, ${ }^{27}$ a 1939 English case, a prominent obstetrician performed an abortion upon a fifteen year old rape victim and was charged with the "unlawful procuring" of abortion (which at that time was permissible only to save the pregnant woman's life). The jury rendered an acquittal after being instructed by the trial judge that Dr. Bourne was not guilty if, on reasonable grounds, he believed that "the probable consequence of the continuance of the pregnancy would be to make the patient a physical and mental wreck. ${ }^{128}$ In short, the Court recognized that a situation of medical necessity could excuse the criminal act. It did so by ruling that the defence was implied by the word "unlawful," as an unlawful procuring implied that the

Ibid.

R. v. Mataya (24 August 1992), (Ont. H.C.J.) [unreported] Wren J.; R. v. de la Rocha (2 April 1993), Timmins (Ont. Ct. (Gen. Div.)) [unreported] Loukidelis J. For $R$. v. Mataya, see A. Mullens, "A question of mercy killing" The Toronto Star (15 October 1994) 1A, 4A. For $R$. v. de la Rocha, see S. Chung, "Ex-city MD admits lethal error" Winnipeg Free Press (15 April 1995) A9.

[1938] 3 All E.R. 615 (C.A.) MacNaghten J. [hereinafter Bourne].

Ibid. at 619. 
room was open for circumstances in which the procuring would be lawful. In other words, the Court derived the defence as a matter of statutory interpretation.

In the 1969 Australian case of $R$ v. Davidson, ${ }^{29}$ the trial judge in the Supreme Court of Victoria likewise ruled that the use of the word "unlawfully" in the Crimes Act 1958 - "unlawfully administers ... any ... noxious thing, or unlawfully uses any instrument or other means" - enabled the accused-physician to present a defence of necessity to a charge of procuring miscarriage. As in Bourne, the jury was instructed that the accused acted lawfully if he reasonably believed that the act "was necessary to preserve the woman from a serious danger to her life or her physical or mental health. ${ }^{130}$ The jury acquitted.

In 1975, nine years before its ruling in Perka, the Supreme Court of Canada first considered the defence of necessity in a case of criminal abortion. In $R$. v. Morgentaler, ${ }^{31}$ the accused-physician had terminated a patient's pregnancy in Montreal without first securing the approval of a therapeutic abortion committee as then required under the Criminal Code. ${ }^{32}$ His defence was that it was necessary to bypass the bureaucratic procedure because the patient was in a heightened state of anxiety that so jeopardized her physical and mental health that time was of the essence. In a six to three opinion, the Court ruled that the facts were not sufficient to establish a defence of necessity. The majority opinion by Justice Dickson (as he then was) did acknowledge that such a defence is allowable as a matter of common law "in urgent situations of clear and imminent peril when compliance with the law is demonstrably impossible. ${ }^{133}$ However, he ruled that there was no evidence in the instant case to support the defence. On the other hand, Chief Justice Laskin argued in dissent that the defence of necessity should have gone to the jury. He referred to the evidence of Dr. Morgentaler that he feared that his patient might well attempt suicide unless he acted quickly to abort the fetus. According to the Chief Justice, the "jury was entitled, if it so chose, to consider this evidence as raising an emergency situation"34 sufficient to relieve the accused of the duty to seek the mandated committee approval.

In the result, all nine justices recognized a common law defence of necessity, even though its parameters were only lightly sketched. In the following year, the Quebec Court of Appeal considered another of Dr. Morgentaler's abortion trials, in which necessity was the sole defence left with the jury. ${ }^{35}$ The Crown appealed the acquittal, which the Court denied by ruling that the trial judge did not err in instructing the jury on the defence of necessity. The reason was that there was sufficient evidence to warrant the instruction. Unfortunately, the Court did not discuss the nature of that

[1969] V.R. 667.

Ibid. at 672 , Menhennitt J.

R. v. Morgentaler (1975), 20 C.C.C. (2d) 449 (S.C.C.) [hereinafter Morgentaler].

In 1988, the therapeutic abortion committee procedures were struck down as unconstitutional by the Supreme Court in yet another Morgentaler case: $R$ v. Morgentaler, [1988] I S.C.R. 30.

Supra note 31 at 497.

Ibid. at 478.

R. v. Morgentaler (1976), 27 C.C.C. (2d) 81 (Que. C.A.). 
evidence. The Court cited the Supreme Court's decision in the 1975 Morgentaler case as the precedent for the common law defence of necessity in Canadian jurisprudence.

In sum, although the defence of medical necessity has been recognized in abortion cases, the Cox case illustrates the unwritten common law rule that it is not available in euthanasia cases. In the Netherlands, on the other hand, the judiciary has carved out what amounts to a defence of medical necessity in cases involving physicians who either give lethal injections to or assist the suicide of consenting patients. We now turn to this exercise in Dutch jurisprudence, which belies the notion that, unlike the common law, rigid adherence to the codified law is a marked feature of civil law jurisdictions.

\section{EUTHANASIA AND THE EVOLUTION OF THE DEFENCE OF MEDICAL NECESSITY IN DUTCH LAW}

The euthanasia issue entered Dutch public consciousness in 1973, when a physician was prosecuted under article 293 for the mercy-killing of a seventy-nine year-old nursing home resident. ${ }^{36}$ The deceased was not a patient of the accused, Dr. Geertruida Postma. Rather, she was the accused's mother, and she had repeatedly beseeched her daughter to end a life rendered unbearable by a cerebral haemorrhage, partial paralysis, deafness and incontinence. Dr. Postma finally complied by giving an injection of 200 milligrams of morphine directly into a vein. She was arrested after informing the nursing home director of her act and brought to trial before the Leeuwarden District Court. The accused had been prompted to act after finding her mother propped in a chair with her arms tied; a nurse had decided that she needed to spend time out of bed. She testified that, "When I watched my mother, a human wreck hanging in that chair, I couldn't stand it any more. So I shouted in her ear, 'It's all right, Mother. I will take care of you.' The next day I gave her the fatal shot." ${ }^{37}$

When asked whether her mother's suffering had become "unbearable," she replied, "No, it was not unbearable. Her physical suffering was serious, no more. But the mental suffering became unbearable." That "was most important to me. Now, after all these months, I am convinced I should have done it much earlier." ${ }^{38}$

The Court also heard from a nurse who had daily contact with the patient and who testified that she repeatedly said to him, "Isn't there anything to kill me, I want to die, just let me die." The accused was convicted and placed on probation for one year. However, the Court then proceeded to specify guidelines that would exonerate an accused charged under article 293: the patient must be incurably ill and afflicted with irremediable suffering; the patient must explicitly ask the physician to end her life; and the act must be performed by the patient's treating physician or by a medical colleague. It is noteworthy that the public reaction to Dr. Postma's deed was largely favourable, 
and eighteen physicians signed an open letter to the Minister of Justice avowing that they had resorted to mercy-killing at patient request. ${ }^{39}$

Eight months after the Postma trial, the Executive Committee of the Royal Dutch Medical Association (K.N.M.G.) issued a working paper on the medical practice of euthanasia. The document confined its focus to the scenario in which a physician administers a lethal injection to a consenting patient, as the committee regarded physician-assisted suicide as a separate issue that it was not prepared to consider at that time. Its view was that the law should allow a defence to a physician charged under article 293, who "shortens the life of a (consenting) patient who is incurably ill and in the process of dying." ${ }^{40}$

In 1981 a layperson was convicted by the Rotterdam District Court for assisting the suicide of a grievously ill friend. However, the Court went on to enumerate the following criteria under which a physician - and only a physician - could lawfully bypass the article 294 ban on assisted suicide: the patient is experiencing unbearable suffering; there is informed consent (the patient understands her condition and prognosis, and the decision to end her life is her voluntary choice); and there are no reasonable alternative measures to alleviate her distress. ${ }^{41}$

The pivotal year was 1984, when the medical practice of euthanasia was endorsed in turn by the Executive Committee of the K.N.M.G. and the Netherlands Supreme Court. The policy position of the medical body was presented in a report titled "Vision on Euthanasia," published in its official journal, Medisch Contact. ${ }^{42}$ In its 1973 working paper, the K.N.M.G. had restricted its definition of euthanasia to the lethal injection scenario. A decade later its view was that: "[i]t makes no difference whether the lethal medicine is administered directly by the physician or that a physician assists the patient in administering it himself." If the former is acceptable then so is the latter, since there is no moral distinction between these two means whereby the physician responds to the mentally competent patient's plea for a drug-induced death. As such, the term "euthanasia" appropriately applies to both cases. According to the Report, the resort to euthanasia does not breach the code of medical ethics provided that the following conditions are satisfied:

1. It must be the patient's decision, the exercise of her free will and not the decision of her family. The patient must be mentally competent; her plea for death must be discounted if it is the product of a disordered mind affected by psychiatric illness. The patient likely will consult with her family regarding such a momentous matter, but that is beside the point. In fact, if the patient does not wish the family to know that she is asking for euthanasia, the physician must respect that wish. The Report stresses the voluntariness of the

39 District Court of Leeuwarden, N.J. 1973, No. 183.

40 Royal Dutch Medical Association, "The Problem of Euthanasia" (1973) 28 Medisch Contact 857.

$4 \quad$ H.J.J. Leenen, "Euthanasia, Assistance to Suicide, and the Law" (1987) 8 Health Policy 197.

42 Central Committee of the Royal Dutch Medical Association, "Vision on Euthanasia" (1984) 39 Medisch Contact 990. 
request. If communicated in the presence of the family, the physician must confer privately with the patient. Since the desire for death must be "consistent, durable, and well considered," the caveat is that the patient must have "a clear picture of her medical situation and the appropriate prognosis."

2. The patient's request cannot be granted unless she is experiencing "unacceptable and hopeless suffering that cannot be rendered bearable." By unbearable suffering, the Report means either "unbearable physical pain" or "unbearable mental suffering as a result of a physical disorder." The latter is illustrated by the hypothetical example of a patient with multiple sclerosis who is totally paralyzed. The Report also states that given current pain-control techniques, euthanasia is a rarely justifiable response to physical pain.

3. In its earlier (1973) statement on euthanasia, the K.N.M.G. had stipulated as a qualifying condition that the patient must be in the so-called "terminal phase." It now scraps that requirement. Since the focus is upon a compassionate response to unbearable and unrelenting suffering that causes the patient to prefer death to life, it is unduly restrictive to insist that death be at hand. In this regard, it refers back to the example of the totally paralyzed multiple sclerosis patient.

4. The physician must consult with an experienced colleague before complying with the patient's request.

Three months after the publication of the K.N.M.G.'s "Vision on Euthanasia," the Supreme Court of the Netherlands rendered its decision in the landmark Schoonheim case, ${ }^{43}$ which is the first of the five euthanasia cases presented in this article. (The cases appear in chronological order as dating from the patients' deaths.) In the first two cases, Schoonheim and Admiraal, ${ }^{44}$ the physician was charged under article 293 with administering a lethal injection to his patient. Dr. Schoonheim's patient was ninety-five years old and her condition was such as to warrant a prognosis of terminal illness (death within months, if not sooner). Dr. Admiraal's patient was thirty-four years old and was totally paralyzed from the ravages of multiple sclerosis, but she was not terminally ill. (In other words, she fit the description of the K.N.M.G.'s hypothetical case of a patient not in the "terminal phase.")

In the third and fourth cases, Kors ${ }^{45}$ and Duintjer, ${ }^{46}$ the physicians were charged under article 294 with aiding suicide. Dr. Kors' patient was a twenty-five year old anorexic with a sixteen year psychiatric history. Dr. Duintjer's patient was fifty years old with a twenty-five year psychiatric history. The fifth case, Chabot ${ }^{47}$ also involved a charge of aiding suicide. The patient was fifty years old with no psychiatric history 
but was desperately unhappy because of personal family tragedy. In the Kors, Duintjer and Chabot cases, the patients were not suffering from underlying physical disorders. As the Dutch would phrase it, they were cases of "non-somatic" suffering. The three cases thus go beyond the "unbearable suffering" criterion in the 1984 K.N.M.G. guidelines, requiring either "unbearable physical pain" or "unbearable mental suffering as a result of a physical disorder."

Critics of the Dutch euthanasia policy see this progression in patient eligibility as proof that the spectre of the slippery slope has come to pass. The contrary view is that the cases represent a logical and legitimate progression in the commitment to the two principles of bio-medical ethics that ground the Dutch euthanasia policy: patient autonomy and beneficence/mercy. (We ask the reader to reserve judgment on this matter until the conclusion of the article.)

In any event, we begin with the Schoonheim case. The presentation of the facts is based upon an interview with the defence counsel, Eugene Sutorius. Mr. Sutorius is a partner in the Arnhem law firm of Winters and Bosnak, and he acted for the accused in four of the five cases. Although he was not the attorney of record in the Admiraal case, he was thoroughly involved as consultant to the defence. In other words, we can trace the hand of one lawyer in the defence of each of these five cases. ${ }^{48}$ (Mr. Sutorius also has a part-time appointment as a deputy judge in the Amsterdam Court of Appeal and is a frequent guest lecturer in Dutch law faculties.)

\section{FIVE PIVOTAL DUTCH EUTHANASIA CASES}

\section{A. THE CASE OF DR. SCHOONHEIM (FAMILY PHYSICIAN)}

\section{The Facts}

In 1982 Attorney Sutorius was asked by a family physician, Dr. Schoonheim, to defend him against a charge under article 293 of the Dutch Penal Code for deliberately giving a lethal injection to a ninety-five year old patient. The accused related the following account of the circumstances that had led to his arrest.

The names of the patients in the Schoonheim and Chabot cases are given because they were identified in the Dutch media. Pseudonyms are given for the other three patients because their names did not appear in the media. Dr. Duintjer is also a pseudonym because he was not publicly identified by name. The names of the other four physicians are given because they were identified in the media. Much of the information on the five cases was provided by Attomey Sutorius from court documents. We also consulted the writings of Dr. Chabot, who has written an article about his case and the Kors and Duintjer cases, and a book about his own case. The former is referenced as follows: B.E. Chabot, "Hulp bij zelfdoding: drie rechtszaken" (1993) 7 Maandblad Geestelijke Volksgezondheid 717. The latter is B.E. Chabot, Zelf Beschikt (Amsterdam: Uitgeverij Balans, 1993). This book is translated into English as an unpublished manuscript, entitled Chosen Fate. We have not used footnotes in the discussion of the five cases. Suffice it to note that our sources are from the court documents, interviews with Attomey Sutorius, and the Chabot writings, which are of course in Dutch (except for Chosen Fate). Professor Verhoef may be contacted for access to these materials. 
Maria Barendregt had been his patient for six years, when at the age of eighty-nine she had moved to a nursing home in a small village in the northern part of Holland. She was a mentally unimpaired person who prided herself on her independence. But as the years mounted, the infirmities of old age steadily took their toll: she experienced increasing difficulty in walking, loss of acuity in vision and hearing, and frequent dizzy spells. As her condition deteriorated over time, she often asked Dr. Schoonheim whether he would consider giving her a lethal injection. His consistent failure to respond was indicative of his aversion to discuss the subject of euthanasia with his elderly patient.

In 1981 Mrs. Barendregt fractured her left hip in a fall and when surgery was advised, her response was that she would consent only if she did not live through it. The surgeon naturally declined to operate. She was then transferred to the nursing home's hospital unit where she became a bed-ridden patient, waiting and praying for death. She could no longer walk nor even sit up, and from time to time she found herself unable to talk. She was permanently catheterized because of total incontinence and otherwise totally dependent on the nursing staff for her bodily needs. Yet, she remained perfectly coherent and fully conscious; and she continued to beseech Dr. Schoonheim to end her life. As a person always known for her independence, she agonized over her progressive degradation as she became steadily less able to communicate with those around her.

By the last week of her life, she could no longer take liquids nor speak and was suffering periodic lapses of consciousness. However, when she regained some ability to speak, she adamantly expressed her horror at the fact that she was still living. She also begged her son to urge upon the physician the necessity to end her life at the earliest possible moment. At the same time, she reiterated that plea directly to Dr. Schoonheim and his assistant (a young physician working in his office).

What then happened was a series of talks between the patient, her son, and the two physicians, culminating in Dr. Schoonheim's decision to comply with Mrs. Barendregt's desperate desire for euthanasia. The next morning, the patient had a long farewell with her son and daughter-in-law, during which she expressed her gratitude to Dr. Schoonheim for his devoted care and for finally agreeing to terminate her life. She said to them, "Always honour this doctor."

At 11:30 A.M. on July 16, 1982, Dr Schoonheim and his assistant attended at her bedside, and once again she was asked whether she still wished to die. Her response was clear and to the point, "If it can be done, please do it at once, quickly, not one more night." The two physicians briefly left the room to enable the family to say their last goodbye. Immediately thereafter, Dr. Schoonheim rendered the patient unconscious by injecting diazepam and thiopental, followed minutes later by an injection of curare (a muscle paralysing drug) that caused her death by respiratory arrest. 
2. The Law

Attorney Sutorius presented an article 40 defence, namely that Dr. Schoonheim had acted in a state of necessity. The trial court agreed but the acquittal was overturned by the Amsterdam Court of Appeal on the grounds that the defence of necessity could not be allowed to undermine the article 293 prohibition against consensual mercy-killing. The Supreme Court in turn reversed that decision by denying its underlying premise. It accordingly ruled that the issue was whether the accused had in fact acted in circumstances sufficient to establish a defence of medical necessity.

Although Dutch courts had on occasion dealt with cases invoking the article 40 defence, Schoonheim was the first case in which the defence was presented in the context of professional responsibility. The Supreme Court thus had occasion to refine the defence in the euthanasia context. In that regard, the Court conceptualized the defence around the concept of "conflict of duties" - when the physician is faced with an irreconcilable conflict between his duty to abide by the law and his duty to help his patient who pleads for active intervention to end a life marked by unbearable and irremediable suffering. In other words, the physician is caught in an ethical dilemma which he resolves by breaking the law in the interest of what is considered a greater good: heeding the plea of his mentally competent patient to end a life rendered intolerable by the ravages of disease.

According to the Court, the overriding issue was whether Dr. Schoonheim had been confronted with an emergency situation "according to responsible medical judgment, tested by norms of medical ethics." Because the Supreme Court is not the final arbiter of the facts in Dutch law, it sent the case down to a lower court to apply its direction on the law to the facts surrounding the patient's death. In the process, it directed the court to consider: (1) whether according to professional medical judgment it was likely that Mrs. Barendregt would experience increasing "disfigurement" of her personality and/or a worsening of her already unendurable physical and mental suffering; (2) whether the spectre of further deterioration made it necessary for Dr. Schoonheim to act when he did to enable the patient to "die with dignity"; and (3) whether there were less drastic means to alleviate her suffering.

When all the medical witnesses in the subsequent hearing supported Dr. Schoonheim's action, the public prosecutor responded by dismissing the charge. It is noteworthy that it was not the medical testimony alone that prompted the prosecutor to terminate the proceedings. He had sought the advice of the K.N.M.G. as to whether the circumstances of the case fell within the medical guidelines. Its response was that "if the criteria of voluntariness, a well considered request and unbearable suffering have been met ... euthanasia is in principle allowed." It is thus hardly surprising that the charge was dismissed, given that the medical witnesses and the K.N.M.G. had presented a united front favourable to Dr. Schoonheim's action. ${ }^{49}$ 
Furthermore, by omitting to stipulate that the euthanasia candidate must be in the socalled "terminal phase," the Supreme Court's decision in the Schoonheim case could be interpreted as in alignment with the K.N.M.G.'s position that euthanasia not be restricted to the terminally ill. (In any event, a year later the District Court of the Hague would approve the euthanasia of a non-dying patient in the Admiraal case.)

In two other respects, the law as it has unfolded is in accord with the K.N.M.G. criteria: it is only physicians who can lawfully perform euthanasia and the euthanasia guidelines apply to both lethal injection and assisted suicide cases. ${ }^{50}$ Must the patient be an adult? Although the K.N.M.G. and the courts have yet to address this issue, Dutch physicians and lawyers have expressed the view that so-called "mature minors" (older minors with sufficient maturity to make informed judgments) would qualify.

Finally, there is irony in the fact that in Schoonheim, the Dutch Supreme Court has fashioned a defence to a charge of unlawful homicide that exonerates the accusedphysician only when she has committed an act that in Canada (and elsewhere in the common law world) is defined as first degree murder (i.e. the planned and deliberate consensual killing of the deceased). In other words, it is the mental element of the death-dealing act, its planned and deliberate nature, that grounds a defence of necessity under article 40 of the Dutch Penal Code.

We have seen that in the context of medical necessity, article 40 contemplates a case in which the physician feels compelled by the overpowering force of circumstances to comply with the patient's request to end his life. Even so, the physician cannot act on the impulse of the moment but rather must stay her hand until convinced that the case falls within the prescribed medico-legal guidelines. In that sense, the necessitous act lacks the urgent sense of immediacy that prompts an accused to act on the sudden (as in the hypothetical case of the trapped pilot). On the other hand, the deliberateness of the act calls to mind the dictum in the Holmes case that selection by lot would excuse an act of maritime survival cannibalism.

In the result, the Dutch Supreme Court has indicated that, however overpowering the facts of the particular case, the physician's act is sheltered by article 40 only if she has expended sufficient time and effort to ensure that the plea for euthanasia was the voluntary choice of a mentally competent patient and that there were no other means to relieve his unbearable suffering. That is, after all, as it should be. If the law is prepared to bestow the awesome responsibility and power to practice euthanasia upon the medical profession, an admonition to proceed with due caution is surely a moral imperative. (The same standard applies with equal force to an act of physician-assisted suicide.)

As the policy has evolved, physicians are obliged to fill out a standard form detailed questionnaire on euthanasia cases for submission to the municipal coroner. The latter

Although, as outlined in Chabot (the last of our five cases), the Dutch Supreme Court has made the consultation criterion more strict in assisted suicide cases in which the patient is not afflicted with an underlying "somatic" (physiological) disease process. 
then transmits a report of each case to the public prosecutor with a notation as to whether the physician has complied with the mandated guidelines. An inquiry is pursued in questionable cases, which may lead to a charge under either article 293 or 294 of the Penal Code.

\section{B. THE CASE OF DR. ADMIRAAL (ANAESTHETIST)}

\section{The Facts}

At the time of her death on November 4, 1983, Karin L. was thirty-four years old and had been afflicted with multiple sclerosis since 1976. The progressive deterioration of her condition led to a nursing home admission in 1981, and by the following year she had fantasies of ending her life by propelling her wheelchair down a flight of stairs. She failed to act only because she decided that ending her life in that manner would traumatize her parents.

In December 1982 she asked her physician (who was also the nursing home's director) to end her life, but he refused. By mid-1983 she was completely paralyzed except for the movement of her left hand. She could barely swallow nor speak above a whisper. Her sight was failing and she was experiencing intractable bone pain. Her breathing was becoming more laboured, and although she feared suffocation she was appalled at the thought of artificial ventilation. She was dismayed by her state of total dependency, remarking that she could not even wipe her face nor brush away a fly.

In desperation, she turned to the Dutch Voluntary Euthanasia Society (N.V.V.E.) for help in finding a physician unopposed in principle to euthanasia. She was referred to Dr. Admiraal, an anaesthetist at a nearby hospital. After they had discussed her situation at length, he turned to the terminal care team at his hospital for consultation. There were a number of sessions in which he and the team conferred with the patient and her parents. At Dr. Admiraal's request, her family physician of thirty years standing had a long talk with her about her request for euthanasia. The family pastor was also consulted and informed Karin that he did not oppose her decision. Her wish to die was granted because it was clear to all parties that she was mentally competent and that her intolerable condition bore no prospects for improvement. With her family at her bedside, she met her chosen fate when Dr. Admiraal injected her with thiopental to render her unconscious and then with curare to stop her breathing.

\section{The Law}

Dr. Admiraal reported the case to the police as an unnatural death, and the public prosecutor responded by filing a charge under article 293 of the Penal Code because, in his view, Dr. Admiraal should not have acted without consulting a neurologist. The case was not heard until 1985, when the District Court of the Hague acquitted the accused. In the Court's view, the patient's medical history was sufficient to obviate the need to confirm her prognosis with a neurological consultation. The Court acquitted the accused by ruling that he had scrupulously complied with the euthanasia guidelines 
formulated by the Dutch Supreme Court in the Schoonheim case. The Court did not highlight the fact that the patient was not terminally ill.

Bear in mind that in Schoonheim, the Supreme Court had not declared that eligibility for euthanasia was restricted to the terminally ill; and in Admiraal, the District Court simply assumed that the accused was not barred from acting at the urging of a nondying patient. Since there was no appeal from the acquittal, one can assume that the public prosecutor likewise regarded eligibility for euthanasia as not restricted to those in the "terminal phase." In any event, in 1986 the Dutch Supreme Court held that a physician acted lawfully by administering a lethal dose of morphine at the behest of a seventy-three year old nonterminal patient with multiple sclerosis. As in Admiraal, the fact that she was not terminally ill was not stressed by the Court. ${ }^{51}$ Also note that in Schoonheim the Supreme Court did not stipulate that the patient's unbearable/irremediable suffering must be traceable to a physiological (what the Dutch call "somatic") condition. However, as we shall see, it was not until the Chabot case that the Dutch Supreme Court went out of its way to rule that, in exceptional circumstances, a physician could lawfully assist the suicide of a patient whose suffering was not grounded in a somatic condition.

\section{THE CASE OF DR. KORS (PAEDIATRICIAN)}

\section{The Facts}

At the time of her death on October 31, 1990, Maria S. was a twenty-five year old anorexic weighing a mere nineteen kilos (forty-two pounds). As her longtime paediatrician, Dr. Kors had diagnosed the condition in 1974 when she was eight years old. He had responded with a regimen of tube feeding and also had arranged for treatment as an in-patient in a psychiatric clinic specializing in eating disorders (where she remained from 1974-77). Despite ongoing aggressive therapy, her condition did not improve and over the next few years she required periodic hospitalizations (including a three year stay in another clinic from 1979 to 1982). She was also plagued by extreme anxiety and exhibited obsessive and regressive behaviours (e.g. drinking from a baby bottle until the age of twenty and curling up in her mother's lap in a fetal position).

When Maria was nineteen years old, she managed to graduate from high school and find work as a lab technician. Around that time, her parents divorced and her younger brother Ernst became seriously depressed. When he confided in her that he was thinking of killing himself, she responded that she too wished to die. Years later (six months before her own death), Ernst committed suicide by asphyxiation. At his funeral, Maria announced her intention to follow suit. She had on previous occasions asked Dr. Kors to assist her suicide (he remained her treating physician until her death), and her brother's death prompted her to renew that plea. 
It was a few months later that Dr. Kors finally agreed that the time had come to consider her persistent request for assisted suicide. Determined to die, Maria had resolved to refuse further tube feeding and hospitalization. She was by now vomiting incessantly and experiencing severe stomach pains. As she told Dr. Kors, "When Ernst died, I knew that finally I was allowed to go as well. I cannot go on any longer. I want salvation now. Therefore, I am asking you as a friend to help me. Please help me."

Dr. Kors decided to help her because after sixteen years of treatment his patient weighed nineteen kilos, and in his view there was absolutely no likelihood that her condition would improve (her weight was twenty-seven kilos when the symptoms of anorexia had first appeared, and she had never weighed more than thirty kilos). He had finally come to the view that her situation was indeed hopeless, agreeing with Maria that she had "no good quality of life." He later remarked, "When your patient keeps asking for death and the therapy remains unsuccessful, you should listen carefully to what the patient is asking."

Dr. Kors consulted a psychiatrist who had seen Maria on numerous occasions at his request, and the psychiatrist proceeded to a lengthy discussion with Maria about her situation. He reported to Dr. Kors that in his clinical opinion, the patient was mentally competent and that there were no treatment options that held the prospect of easing her mental suffering. Although the patient could have been force-fed, Dr. Kors considered such drastic means as morally indefensible in light of Maria's vehement objection to such treatment. Furthermore, because she was mentally competent, she could not legally be fed against her will. In any case, although forced feeding could have kept her alive in the short run, that option held no hope of dissuading Maria from her resolve to end her life.

When Dr. Kors finally agreed to provide the drugs to enable her to commit suicide, Maria signed her last will and testament and then arranged for a videotape so that she could explain her reasons for ending her life. She was devoted to Dr. Kors and thought that the video would assist his case in the event that he was prosecuted. In the ten minute video, the patient is seen from the waist up and standing against a wall. One sees what appears to be an emaciated ten year old girl with a sallow complexion and hollow eyes. She has the appearance of a concentration camp survivor. Her comments in the ten minute video include the following:

In the beginning I was looked at as an obstinate child. But I was not obstinate to my parents, my doctors, and the people around me. Instead I was battling with myself. I was punished by others because I didn't want to eat. But in fact I was punishing myself. The more people punished me, the more I punished myself. I want to thank Dr. Kors who has helped me for over fifteen years. First when I was a child he was my doctor. Later, he was my friend to whom I wrote letters and now he is my friend, my doctor, and my second father. It became so bad that my entire life became a torture. I was starving myself not because I wanted it. I was hungry, but I didn't like to eat. Everything I used to like I didn't like any more. And so I grew very slowly in the twenty-five years I've lived, very slowly, I grew toward my death. I've thought about dying day and night, and I know that if the relief does not come I will return to the old pattern, the pattem of self-punishment, hurting myself. I know it, I feel it and therefore I hope the release will come soon, that I die. People have been very loving to me in 
the last while. Therefore, it hurts me very much to say goodbye. But I know I can't stay alive any longer for all those nice people. Now for once I think about myself. I can't go further. I am in pain physically and mentally. Therefore, I've decided this is the best road.

Maria also wrote a letter to Dr. Kors, expressing her heartfelt thanks for his steadfast care and friendship. As she concluded, "I write this letter crying, crying out of sorrow because I am leaving my friends, and crying out of joy because relief is imminent."

She ended her life five days after making the video by ingesting a lethal dose of seco-barbital provided by Dr. Kors. He reported the death to the authorities, and the public prosecutor responded by charging him with aiding her suicide under article 294 of the Dutch Penal Code.

\section{The Law}

Attorney Sutorius filed a complaint against the decision to prosecute with the trial court (the District Court of Almelo). He followed this course because Dutch criminal procedure allows a judge to quash a prosecution when there is defence evidence sufficient to indicate a high degree of probability that the accused would be acquitted. Along that line, he presented an interwoven two-pronged argument that would also ground his defence in the Duintjer and Chabot cases.

First, he contended that the provision in the Dutch Constitution that guarantees "equality before the law" precluded a euthanasia policy restricted to patients with somatic-based suffering. As he readily acknowledged, the source of the patient's suffering cannot be ignored because doing so would prevent her caregivers from considering the possibility of measures to alleviate her distress. However, once it is determined that the patient's suffering is unbearable and irremediable, then the source of her torment is really beside the point. In that sense, what counts is the fact of that suffering, not its source. After all, whether the patient is afflicted with a somatic condition (e.g. cancer or multiple sclerosis) or with a nondiseased body encasing a tortured soul, suffering is a mental process whose magnitude is not conditioned upon its origin in the body or the mind. In either case, the patient can experience her continued existence as a living hell with no way out except the merciful release of death.

Furthermore, since the euthanasia policy is buttressed by the twin pillars of autonomy and beneficence, the mentally competent patient whose suffering is non-somatic surely qualifies to the same degree as her counterpart whose suffering stems from a physical disease process. In Sutorius's view, a patient's role as an autonomous agent is not compromised simply because her decision to die originates from a non-somatic condition. Beyond that, the resort to euthanasia is a beneficent act because it enables the patient, regardless of the source of her suffering, to sanction the end of a life whose burdens have overwhelmed its benefits.

In response to his petition to dismiss, the District Court (trial courts in the Netherlands are presided over by three-judge panels) appointed an investigating 
magistrate to inquire as to the facts of the case. In the course of his assignment the magistrate interviewed four of Maria's caregivers (a family physician, a psychologist and two psychiatrists) and the family's pastor. The Court then proceeded to an in camera hearing, in which it heard from Dr. Kors, a psychologist, two medical specialists in eating disorders who had not treated Maria and an ethicist. The witnesses called by the defence all agreed that the patient's condition was indeed beyond remedy and that she was mentally competent. They also sided with Dr. Kors that from an ethical standpoint he could not subject her to forced feeding.

The Court was satisfied from the evidence that the medico-legal guidelines had been satisfied: the patient was free of psychosis and was otherwise mentally competent; her wish to die was well considered, persistent, and the product of her free will; her suffering was relentless and intolerable; and finally, there were no reasonable treatment regimens to ameliorate her condition. (Recall that in Schoonheim, the Supreme Court ruled that a patient does not forfeit her right to euthanasia solely because she rejects a proposed regimen that conflicts with her moral code. This does not mean that the patient can qualify for euthanasia as the measure of last resort by rejecting all treatment options. It remains the court's task to assess the reasonableness of her refusal. In any event, as Sutorius points out, it would have been pointless to insist that Maria eat to stay alive, given that it was life itself that had become her torture chamber.)

Moreover, the Court rejected the contention of the prosecution that the medico-legal criteria be interpreted such that a physical disease process must underlie the patient's suffering. Instead, the Court accepted the submission by the defence counsel that what counts is compelling evidence that the patient's suffering is unbearable and cannot be relieved. The Court agreed that it follows that the source of that suffering - whether physical or psychological - is not the controlling factor. What matters is rather the experience of the suffering itself. The Court accordingly granted the motion to dismiss and its decision was not appealed by the public prosecutor.

\section{THE CASE OF DR. DUINTJER (PSYCHIATRIST)}

\section{The Facts}

At the time of her death on October 4, 1985, fifty year old Martha N. was married and had two adult children. She had a history of depression and alcohol abuse dating back about twenty-five years, which occasioned numerous admissions to psychiatric facilities (including ten in her final five years). She was diagnosed as suffering from a character neurosis with depressive and dependent traits and a strong self-depreciation leading to suicidal ideation. In short, she was a deeply unhappy person whose thoughts constantly turned to suicide as the only means to end her distress.

Although she had undergone various treatment regimens over the years, she would regularly skip doctors' appointments and fail to take her medication. During the last few years of her life, she experienced numerous bouts of depression which she found unbearable and which led her to describe her life as "one big black hole." Martha became Dr. Duintjer's patient in 1981, the same year as the first of her many requests 
for physician-assisted suicide. She had been referred to him by her new family physician, Dr. W.

Albeit some of her actions were more in the nature of suicidal gestures, there were also deadly serious attempts to end her life. In 1983 Martha drank a household cleanser containing chloride which damaged her vocal chords. The next year she set herself on fire and then a month later jumped out of a second story window, fracturing her ankles and a disc.

Although her husband and children were caring and supportive over the years, her bizarre behaviour inexorably took its toll. Her relationship with her family slowly slid downhill, and by 1983 she had chosen to isolate herself in her bedroom. She kept the curtains closed, would often deny access to her husband or children (although her daughter had moved out, her twenty year old son still lived at home) and on such occasions would scream if anyone tried to enter. In the result, her husband and children were emotionally drained by the constant stress.

She had repeatedly asked both Dr. Duintjer and Dr. W. to assist her suicide, and her pleas had become more frequent and persistent over time. In September 1985 she took an overdose of sedatives she had obtained by falsifying a prescription, an act that at last persuaded her two physicians to consider helping her to die.

The physicians agreed to meet with the patient to consider her request, but illness by Dr. Duintjer prompted him to cancel the meeting. It was rescheduled at the patient's insistence and Martha N., her husband and the two physicians accordingly met on October 1. By the discussion's end, the husband had come to accept her decision (although as noted, the medico-legal guidelines do not require spousal consent to euthanasia). By now, Dr. Duintjer was prepared to accept that there were no treatment modalities that could ease her distress. It was clear that she desperately wanted to die, not only for her own sake but also to put an end to the constant stress and turmoil that her condition imposed upon her family. Furthermore, she had a clear understanding of her situation and was mentally competent to ask for medical assistance to end her life. That Dr. W. fully concurred with his assessment was enough to satisfy Dr. Duintjer, which explains why he did not seek confirmation from another psychiatrist that the euthanasia criteria had been met.

Dr. W. also arranged for her pastor to become involved in the case. After about a dozen meetings with Martha, he reported back that he had come to the view that her case was hopeless, that she was indeed determined to die, and that the physicians were morally entitled to assist her to that end. In anticipation of her suicide, the patient composed and signed the following statement on October 3, "I declare that life has no more value to me and that I voluntarily and in full consciousness, at my time and with the method of my choice, wish to end this life."

On the following day the patient died after ingesting a lethal dose of cyclobarbital provided by Dr. Duintjer. When he reported the case, the public prosecutor responded by charging him with aiding suicide under section 294 of the Dutch Penal Code. (A 
judicial process was set in motion that was not finally resolved until eight and a half years later!)

\section{The Law}

As in the Kors case, Attorney Sutorius filed a motion to stay the prosecution. That issue was not resolved until the Dutch Supreme Court affirmed lower court rulings that had denied the motion. The case then went to trial in the Rotterdam District Court, where the accused was acquitted. The Court found that the medico-legal criteria had been satisfied: the patient was mentally competent and was acting out of her free will; she had made persistent requests to die; and there were no alternative measures that could relieve her intolerable suffering. As in Kors, the Court drew no distinction between somatic-based and purely mental suffering. There was, however, an extensive commentary on the nature of suffering, in which the District Court concluded that the issue was not the cause of the patient's affliction but rather its manifestation and extent.

The prosecution appealed the decision but the acquittal was upheld by the Court of Appeal of the Hague. The appellate Court rejected the argument by the prosecution that psychiatric patients were by definition mentally incompetent to qualify for euthanasia. It also agreed with the District Court that Martha $\mathrm{N}$. was mentally competent and that there were no treatment prospects likely to alter her situation.

The Court of Appeal admonished the accused for failing to consult a physician not involved in the patient's treatment. However, it let the verdict stand because of the compelling testimony by psychiatrists and psychologists, who had been treating her for years (both in and out of hospital), that the patient's suffering was indeed unbearable and irremediable. The Court also stated that it was proper for Dr. Duintjer to consider her avowed intention to kill herself as a factor to be weighed in the evaluation of her request for assisted suicide.

There was a further appeal to the Dutch Supreme Court, which declined to review the case because the prosecutor had not filed his appeal notice within the prescribed time period. By so ruling in 1994, the Court laid to rest a matter that had originated with the patient's death in 1985. In sum, the Supreme Court never considered the merits of Dr. Duintjer's case of assisted suicide.

\section{E. THE CASE OF DR. CHABOT (PSYCHIATRIST)}

\section{The Facts}

At the time of her death on September 28, 1991, Hilly Bosscher was a fifty year old social worker and, unlike the patients of Drs. Kors and Duintjer, she had no history of psychiatric disorder. She had married at the age of twenty-two to escape from her strong willed mother and claimed that the marriage had quickly gone sour. Her husband was an alcoholic who often subjected her to physical abuse. At her initiative they went through a bitter divorce in 1988 . 
Still, her dreary marriage was not the source of the profound unhappiness that prompted her rendezvous with Dr. Chabot. Rather, her flight from life stemmed from domestic tragedy of such magnitude - the deaths of her only two children (Peter from suicide at the age of twenty and Rodney five years later from cancer, also at the age of twenty) - that she simply lost all will to live.

The first crushing blow happened in 1986 when Peter shot himself after his girlfriend terminated their relationship (he was a soldier stationed in Germany and killed himself while on guard duty). As a loving parent, Hilly was devastated by his death and sought psychiatric counselling to help her work through the grieving process. However, she soon called a halt to therapy because of her conviction that no one could really help her come to terms with her sorrow and anguish. As time passed, she was able to get on with her life, sustained by the presence of her beloved younger son.

When Rodney was stricken with cancer four years later, she quit work to concentrate her energies on helping care for him at home and in the hospital. As his condition deteriorated, she resolved that once he died she would commit suicide. (As she later expressed it to Dr. Chabot, "During his illness I had only one thought: when he is not here any more I don't have to stay either.") Rodney died on a May morning in 1991 and that afternoon, Hilly purchased three adjoining cemetery plots, intending that Peter's remains be moved so that she be buried between her sons. That evening, she attempted suicide by swallowing pills and was appalled when she regained consciousness thirty-six hours later. Two months later, Hilly confided in a letter to a friend that her life had become meaningless without her sons and that she fervently wished to die.

I really cannot live without my children. I'm sitting in the kitchen to write, but wherever $I$ am, everywhere is Rodney. My head reels with thoughts. Incomprehensible, all that is stored in your head. Incomprehensible also that my body keeps going, while everything wants to die. Peter has been reburied with Rodney. Between them is my grave. I long for the day that I don't have to get up any more and that I can lie between my boys forever. You know that my life centred around my boys. It was horrible to live after Peter's death, and I only succeeded because I still had Rodney. Time heals all wounds, they say. Not these wounds.

She remained obsessed with the thought of suicide but had no access to a lethal dose of drugs and balked at the prospect of a violent death. Her train engineer father had been traumatized by the deaths of desperate people who over the years had leaped upon the tracks in his train's path. Hilly was haunted by his accounts of these grisly incidents and was determined to die without fuss and without inconveniencing others. She also feared that if she failed another suicide attempt, she would be taken to a psychiatric facility. She asked her family physician to help her commit suicide but he refused. She met the same response from a nurse, a psychiatric social worker and close friends.

In desperation, Hilly then contacted the Dutch Society of Voluntary Euthanasia (the same organization that had connected Karin L. to Dr. Admiraal). Although the N.V.V.E. informed her that it did not actively assist suicide, it did refer her to Dr. Chabot when she asked for the name of a highly regarded physician who was not 
opposed in principle to assisting suicide. As an experienced and well-respected psychiatrist, Dr. Chabot took particular gratification from the many cases in which he had helped suicidal patients find reason to get on with their lives. At their first session, Hilly was quite insistent that her continued existence was intolerable. Throughout the interview, she clutched a necklace with a locket containing photographs of her two sons. She told Dr. Chabot that three physicians had refused to provide her with a lethal dose of the drug Vesparax (a potent barbiturate-based sleeping pill) and she reiterated the request to him. When he responded by suggesting antidepressants, she replied, "I cannot make it clear but I cannot do it; there is no future."

Although adamant that life held no prospects for her, she did agree to an arrangement with Dr. Chabot which he referred to as "trial therapy" (a mutual attempt to establish a working/ trusting relationship). At his suggestion, she also kept a journal which she shared with him. What emerged from the therapy sessions and her writings was an unwavering determination to die. Her life had revolved around her two sons to such an extent that the role of mother had come to form the core of her identity. Hilly revealed to him that she did not begin to enjoy life until Peter's birth. When her beloved sons died her spirit died with them, and there was nothing that could revive it. When he asked if she believed that by dying she would be reunited with them, her response was: "I won't see them except at the moment of death and then we will disappear together into nothingness."

She not only spurned anti-depressants but also rejected his offer of "bereavement therapy." Hilly told him that she simply was not prepared to undertake the commitment to work with him to change her bleak outlook on life. She was who she was and she could not envision becoming a different person. As she explained in her journal:

I miss every purpose in life. About therapy: I have to change, to be better able to bear it. Why, what for? I have been happy. I have had everything (but) I have lost everything and will never get it back. I do not want to become another person than I was when I was a mother and happy. It is finished, it is all over. For me alone there is no purpose in life. I know who I am or what I am. To become so different that I will want to or have to live means to me that I have to lose again. I am not allowed to be who I am or was. That's not right.

It is this theme that persisted in her journal entries - that her life was so inexorably bound with that of her children that she could not abide living without them:

My life is not important any more. There was a time that I was part of the world. My boys were my partners, my children, my counsellors, my compass. Now the will to die is my purpose. Why are we not allowed to lie there together?

At the beginning of her relationship with Dr. Chabot, Hilly had made it clear what she wanted and that she had no wish to be transformed by therapy into a person prepared to get on with her life. She told him early in their relationship:

What kind of a person am I? Again and again I come to the same conclusion: I don't exist without my children. I do not want to live any longer. I don't want any help. You said that you couldn't do 
anything for me if I wouldn't try any bereavement counselling. It makes me angry when people are telling me that I don't want anything. Just as if I am not a competent person, as if it doesn't count what I say. I don't want to understand. I don't want anything. It's not true. I want to die.

Thus, from the outset Dr. Chabot and his patient were at cross-purposes. She was obsessed with calling life quits whereas he sought to enrol her as a working partner in a therapeutic process designed to give her a new lease on life. As he tried to convince her:

You are in a tunnel where life doesn't penetrate, where you only want to die, where everything seems to point at death. But people come back from that tunnel. Sometimes it is possible to find a way out.

But as Dr. Chabot learned, the patient was not prepared to seek "a way out." Their sessions totalled thirty hours over a two month period, but at no time did any light emerge at the end of the tunnel in which she had confined herself. On August 30, she told him that she had some sedatives and asked whether the dosage would be lethal if swallowed with alcohol. When he said that he thought not, she beseeched him to provide her with a prescription for Vesperax and explained that she would have it filled at various pharmacies until she had enough to end her life. He replied, "If I help someone to die, it will not be in secret."

That same day Dr. Chabot met with her sister and brother-in-law, who told him that her mental suffering was worse than ever and that one of them had to stay with her at night until she dropped off from exhaustion. In their view, there was nothing that could alter her bleak outlook.

By this time, Dr. Chabot was forced to admit that he was at an impasse. Although he had brought the full weight of his extensive experience with bereavement counselling to his sessions with the patient, he had gotten nowhere. In fact, she had refused to accept such counselling because it required that she actively work to come to terms with her grief. As he pondered the patient's insistent wish to die, he considered her case in the context of the medico-legal guidelines that allow Dutch physicians to practice euthanasia. Their short but intense time together had led him to conclude that she was a mentally competent person whose freedom of choice was not constricted by mental illness.

She was not clinically depressed and had never contemplated suicide until Peter's death. In his view, her life had centred on her children because no other figures had met her emotional needs. She had married her husband to escape from her mother but soon found herself trapped in another blind alley. The tenderness, companionship and respect that Hilly anticipated from marriage never materialized. In compensation, she took comfort from the love and devotion of her two beloved sons. Their lives were so intertwined that their deaths severed whatever connection she otherwise had to the world of the living. Hilly Bosscher had suffered a great tragedy and her psychological make-up was such that she had given up on life. One might well regret her decision but one could not thereby conclude that she was mentally incapable of making that choice. Dr. Chabot had never experienced a patient with such an avowed determination to die, 
and he had come to accept that suicide was the only option to end the nightmare that her life had become. He was also convinced that without his help, she would kill herself in any event.

He had transcribed all the sessions with the patient and by pre-arrangement sent copies to four psychiatrists and a clinical psychologist, all of whom were widely experienced in treating patients overwhelmed by the deaths of loved ones. He also consulted a family physician and a theologian-ethicist. There were lengthy telephone discussions with the consultants, four of whom he met with in person. He asked one of the psychiatrists to meet with the patient, but the colleague declined because $\mathrm{Dr}$. Chabot's extensive documentation of the case had convinced him that it was not necessary. All save one reported that it was unlikely that anything could be done to make her life bearable and that they would support his decision to assist her suicide. Among those who supported Dr. Chabot was the clinical psychologist, who is particularly well-known in the field of bereavement therapy. The lone dissenter (one of the psychiatrists) expressed the view that the patient's condition was not hopeless and that he should persist in treating her.

Given the near unanimity of opinion, Dr. Chabot felt assured that he could in good conscience assist Hilly's suicide. Still hesitant to act, he sought counsel from Dr. V., a family physician whose clinical judgment he highly respected. After lengthy discussions of the case, Dr. V. agreed that Hilly's frame of mind precluded any change in her dismal outlook and that she was not mentally ill. However, he was not asked to examine the patient.

There were two final sessions with the patient, who remained steadfast in her determination to die. It was only then that $\mathrm{Dr}$. Chabot finally agreed to assist her to that end, even though he continued to plead with her to give him more time to work with her. Her network of friends and her sister and brother-in-law stood by her, as they had come to understand her wish to die and were "reconciled" to that end.

On the day of her death, Dr. Chabot and Dr. V. attended at Hilly's home, which she had bedecked with flowers. Her dearest friend was also on hand. Dr. Chabot asked her whether she still insisted upon ending her life. She replied, "I am not changing my mind. I want to go through with it." She then led him upstairs to Rodney's room where he gave her the drugs: nine grams of secobarbital, three grams of orfenadrinehydrochloride, and an anti-emetic which she quickly mixed with custard in a bowl. Hilly then asked him to turn on her tape recorder so that she could hear a Bach flute sonata that, at her request, had been played at the funerals of her sons. She lay down on Rodney's bed and her best friend sat with her, stroking her face and hair. She kissed a photograph of her sons and without hesitation quickly ingested the custard. She soon lost consciousness and thirty minutes later Dr. Chabot pronounced her dead. Shortly after her death, he expressed a sentiment that he still holds.

I do not know whether I did the right thing ... but I do believe I chose the lesser of two evils. We can no longer avoid the question of whether, in certain circumstances, people should be allowed to die at a time and in a manner that they feel is appropriate. 


\section{The Law}

Dr. Chabot was acquitted by the Assen District Court of the charge of aiding suicide. The accused testified that in his professional opinion there was no question of a psychiatric illness or major depressive episode. According to the classification system of the American Psychiatric Association (D.S.M.-III-R), Hilly Bosscher was suffering from an adjustment disorder reflected by a depressed mood (though without psychotic signs) in the context of the bereavement process. She was experiencing long-term psychic suffering that for her was unbearable and unremitting. However, she was mentally competent, given that in letters and discussions she had consistently displayed a clear understanding of her situation and the consequences of her decision.

Four of the clinical experts consulted by Dr. Chabot appeared as witnesses for the defence. They all testified that the case had been so well-documented by the accused that it was "highly unlikely" that any new information would have been gleaned by interviewing the patient. The Court of its own accord consulted three additional experts who provided written statements. Of the seven clinicians thus heard by the District Court, not one denied the strong possibility that the patient would have been driven to desperate measures to end her life and not one expressed disagreement with Dr. Chabot's role in her suicide.

Although the patient was suffering from neither a physical nor mental illness, Attorney Sutorius argued that the case fit squarely within the medico-ethical principles of autonomy (self-determination) and beneficence that are the twin pillars of Dutch euthanasia policy. Regarding the former, he argued that respect for the person outweighs the duty to preserve life; and regarding the latter that the relief of unbearable and irremediable suffering likewise overcomes that duty.

The District Court implicitly agreed with his line of argument by omitting to focus upon the cause of Hilly's suffering. Rather, what was legally relevant was compelling evidence that her unbearable suffering (however caused) could not be alleviated. Given its finding that there were no treatment alternatives and that the patient was mentally competent and acting out of her free will, the Court ruled that the accused had acted in compliance with the medico-legal guidelines for physician-assisted suicide.

The Appeal Court of Leeuwarden upheld the acquittal. In the absence of a somatic condition, the Court emphasized that the physician is duty bound to exercise "great care in establishing that the wish to die is not a direct symptom or consequence of a psychiatric sickness or condition and that - in this connection - the request for suicide is well-considered and voluntary." The Court added that, as a general rule, a finding of mental competency is not foreclosed simply because the diagnosis bears the label of a psychiatric syndrome, condition or disorder.

There was a further appeal to the Dutch Supreme Court, which overturned the acquittal in a ruling handed down on June 21, 1994. However, in the result the high Court did not endorse the argument of the prosecution that physician-assisted suicide was permissible only for those afflicted with a somatic condition. In other words, it 
agreed with the two lower courts that the policy encompassed those whose suffering did not stem from a physiological disease process. According to the Supreme Court, it would have been inconsistent with "the specific nature of the defence of overmacht" to accept such a "general limitation." Still, the Court was mindful of the implications of a ruling that did not foreclose the assisted suicide of a non-somatic patient:

But the fact remains that when the suffering of a patient cannot be shown to follow from a somatic illness or condition, and does not consist only of the experience of pain and loss of bodily functions, it is more difficult objectively to demonstrate the fact of suffering and in particular its seriousness and hopelessness. For this reason, the trial court must in such cases approach the question whether there was a situation of necessity with particular care to that factor.

In previous cases, the Supreme Court had rejected an ironclad rule that in somatic cases the treating physician must consult a colleague. Rather, it had ruled that notwithstanding the absence of such consultation, a tribunal could find that the circumstances of a particular somatic case were sufficient proof that the accused had acted in a state of overmacht. In sum, it is a question of fact in the particular case whether the physician should have consulted a medical colleague. According to the Court, the very nature of the defence of overmacht requires an individualized case-bycase approach in which the task before the court is to determine whether the accused had indeed been forced by circumstances to act as he did. Therefore, the imposition of an automatic rule requiring consultation would frustrate the intent of the overmacht defence. Even if such a requirement is appropriate as a general rule, the courts cannot be bound to find as a matter of law that the rule must always be followed.

Notwithstanding that general line of authority, the Supreme Court reversed the Court of Appeal decision in the Chabot case and entered a conviction under article 294 of the Penal Code. In so ruling, the Supreme Court accepted the contention of the public prosecutor that the defence of overmacht was not allowable because none of the experts consulted by Dr. Chabot had personally examined the patient. The Supreme Court agreed that, in a non-somatic case, the absence of a face-to-face examination compels the conclusion that, as a matter of law, the physician may not have truly acted in a state of necessity. Thus, although the Supreme Court rejected a blanket rule that physicians cannot assist the suicide of patients in non-somatic cases, it nonetheless decided that personal contact between consultant and patient was a pre-condition to the acceptance of the defence of overmacht in such a case. Furthermore, its ruling was accompanied by the additional rider that the physician cannot lawfully assist suicide if there is a "realistic alternative to relieve the suffering which the patient has in complete freedom rejected."

Although Dr. Chabot was pronounced guilty for breaching the requirement that the patient be examined by at least one consulting physician, the Supreme Court exercised its prerogative under article 9(a) of the Penal Code to waive "any punishment or other measure" in light of the circumstances of the case and/or the character of the accused. The absence of a sentence is comparable to the Canadian concept of an "absolute discharge" in criminal cases. However, it should be noted that Dr. Chabot now has a criminal record because he stands convicted of the offence of aiding suicide. 
Notwithstanding the waiver of sentence the Supreme Court's resolution of the case is hardly fair. It smacks of retroactivity: an ex post facto ruling that violates the spirit of the rule of law. As Professor Glanville Williams reminds us: in its Latin dress of Nullum crimen sine lege, Nulla Poena sine lege - that there must be no crime or punishment except in accordance with fixed, predetermined law - the maxim has been regarded by most legal thinkers as a self-evident principle of justice ever since the time of the French Revolution. ${ }^{52}$ The citizen must be able to ascertain beforehand how he stands with regard to the criminal law; otherwise it is purposeless cruelty to punish him for breach of that law. In other words, if the rule is not stated, how can one be expected to obey it?

Consider, then, a law that proclaims on June 21,1994 that behaviour $\mathrm{X}$ is a criminal offence and that an accused will be held accountable whether he so acts in the future or whether he had so acted in times past (i.e. when behaviour $\mathrm{X}$ was not proscribed). Our hypothetical proclamation clearly breaches the time-honoured prohibition against ex post facto law, no less than the decision that faulted Dr. Chabot for omitting to comply with a rule that did not exist until after the fact of his omission. After all, had Dr. Chabot known in advance that he would be held accountable for not arranging for at least one of his consultants to meet with the patient (and she was quite willing to do so), then he surely would have taken steps to make that happen. Could not the Court have accomplished its purpose by affirming the acquittal but otherwise ruling that such a requirement is called for in future non-somatic cases?

It has been speculated that, in its ruling in the Chabot case, the Supreme Court was really making a political statement. The reference is to the sentiment that a reversal of Dr. Chabot's acquittal was thought necessary to send the message to the medical profession that the assisted suicide of a non-somatic patient is dangerously stretching the outer limits of the Dutch euthanasia policy. Finally, it is fanciful to believe that any consultant could have persuaded Hilly to change her mind or could have found a "realistic treatment alternative" to assisting her suicide. In that regard, there was never any evidence that such an option was within the realm of the possible.

Finally, Dr. Chabot was also called to account by the Amsterdam Medical Disciplinary Court, which found him guilty of professional misconduct and imposed the sanction of a reprimand. ${ }^{53}$ The Court's ruling was based upon two grounds. First, he was faulted for not pressing the option of anti-depressant therapy more vigorously. Second, whatever the legal position on whether he was bound to arrange that the patient be personally seen by a consultant, the Court concluded that his failure to do so amounted to an ethical breach of duty. Dr. Chabot chose not to exercise his right to appeal the decision to the Central Medical Disciplinary Court in The Hague.

G. Williams, Criminal Law (The General Part), 2d ed. (London: Stevens \& Sons, 1961) at 575. There are five such tribunals in the Netherlands which hear claims of professional misconduct. Each court is composed of a five-judge panel; the presiding judge is a lawyer and the four associates are physicians. The tribunals are empowered to impose the following sanctions: warning; reprimand; fine; suspension; and, the most severe sanction, striking the offender from the medical rolls. The information on the Court's judgment against Dr. Chabot was provided by Attomey Sutorius. 


\section{EUTHANASIA IN THE NETHERLANDS: A MEDICO-LEGAL CONSENSUS}

As we have seen, the pivotal decision in the Schoonheim case followed in the wake of the cautious endorsement by the Royal Dutch Medical Association of the medical practice of euthanasia. The K.N.M.G.'s "Vision on Euthanasia" was the outgrowth of a multi-disciplinary working group (including lawyers, ethicists and theologians) and was thus not the policy position of physicians alone. Although the Supreme Court did not cite the report in Schoonheim, the spirit of its decision was clearly in accord with the medical body's recommendations, particularly as the Court stated that the defence of necessity must be tested "according to the norms of responsible medical judgment, tested by norms of medical ethics." The K.N.M.G. Report had declared that euthanasia was compatible with the ethical practice of medicine, and the Court grounded its judgment in that policy position.

Furthermore, the Supreme Court's ruling in Chabot must be considered against the backdrop of position papers on physician-assisted suicide for psychiatric patients formulated by the Netherlands Association of Psychiatry (N.P.V.) and the K.N.M.G. In 1992, the N.P.V.'s ethics committee issued a Position Paper on Assisted Suicide of Psychiatric Patients, ${ }^{54}$ in which it concluded that there are exceptional cases in which the suicide of psychiatric patients is allowable. In that regard, the psychiatrist is duty bound to verify the following criteria: the voluntary choice and mental competence of the patient; persistent request; unbearable suffering; and no prospect for improvement.

The following year, the K.N.M.G. likewise released a Position Paper on Assisted Suicide of Psychiatric Patients, ${ }^{55}$ in which it came to the same policy position as the N.P.V. (The working group that issued the document adopted as the "Viewpoint" was multi-disciplinary in nature, including psychologists, lawyers and ethicists.) According to the position paper, the crux of the matter is the state of mind of the patient. The issue is particularly complex in psychiatric cases, as the wish may stem from a disorder (e.g. depression or psychosis) that is treatable in the individual case. If, however, the patient's psychiatric disorder is not amenable to treatment, the physician must then determine whether the patient is mentally competent and whether the wish to die is persistent, voluntary and well-considered. Of course, the physician must understand the source of the patient's suffering because otherwise he or she cannot consider alternative measures. Still, as regards the criterion of unbearable suffering, the paper stresses that what counts is the suffering itself, not whether it stems from a somatic or psychological condition. In sum, the issue is whether the suffering that is in place - whatever its source - can be alleviated (a viewpoint that in effect echoes the argument of Attorney Sutorius as first presented in the Kors case). 
On the other hand, if there is a reasonable treatment alternative, then that option must be pursued. Along that line, the K.N.M.G. position paper stipulates that the feasibility of the proposed treatment must be measured by the following criteria: (1) the time frame required for it to take hold; (2) the odds of a favourable outcome; and (3) whether the treatment is unduly burdensome to the patient.

Recall that in Chabot, the Supreme Court stated that a physician could not assist suicide if there was a "realistic alternative to relieve the suffering which the patient has in complete freedom rejected." Hilly Bosscher had refused anti-depressants because she did not "want to become another person." Had she thereby rejected a "realistic alternative" such that Dr. Chabot was legally precluded from helping her die? The Supreme Court did not say. What then of the K.N.M.G.'s three-fold criteria? Although the first and second lend themselves to some kind of objective assessment, the third does not. For who but the patient can say whether a treatment is unduly burdensome, and if burdensome, in what sense - physical, emotional, spiritual? In short, the K.N.M.G. criteria do not answer the question: if applied to the facts of the Chabot case, would the accused be acquitted or convicted? ${ }^{56}$

It is noteworthy that in its ruling in the Chabot case the Supreme Court expressed agreement with the recent N.P.V. and K.N.M.G. position papers. One can thus see that, framed by the Schoonheim and Chabot cases, the Dutch policy on euthanasia is the outgrowth of a collaborative effort by the medical and legal establishments. The medical arm has laid the groundwork for an acceptable euthanasia policy in cases of both somatic-based and non-somatic suffering, and the Supreme Court has followed suit with the law's stamp of approval.

\section{COMMENTARY}

In his short story, "Welcome to the Monkey House,"157 Kurt Vonnegut projects a time when the resources of the planet Earth are strained to the breaking point by a world population of 17 billion people. In desperation, the "World Government" has launched a two-pronged attack on overpopulation. One prong is compulsory birth control. The other is the promotion of "ethical suicide," which involves attending "at the nearest Suicide Parlor and asking a Hostess to kill you painlessly while you lay on a Barcalounger. ${ }^{158}$ In Hyannis, Massachusetts, where the story is set, the local Suicide

There is also the question whether requiring a patient who has no psychiatric illness (e.g. Hilly Bosscher) to submit to anti-depressant medication is a reasonable treatment alternative. Pertinent to this matter is the Declaration of Hawaii, which was adopted by the General Assembly of the World Psychiatric Association in 1977. Section 7 of the Declaration states: "The psychiatrist must on no account utilize the tools of his profession, once the absence of psychiatric illness has been established." (see S. Bloch \& P. Chodoff, eds., Psychiatric Ethics (New York: Oxford University Press, 1991) at 525.) The Declaration has been endorsed by the Board of Directors of the Canadian Psychiatric Association. (For an insightful article on the implications of using anti-depressants to alter the personality of patients with no psychiatric illness, see C. Cebuliak, "Life as a Blonde: The Use of Prozac in the 90s" (1995) 33 Alta. L. Rev. 611.) 
Parlor is a small operation with only six suicide booths. It is run by two attractive Hostesses who have volunteered for the E.S.S. (Ethical Suicide Service) and who "put people to sleep" with a hypodermic needle.

Has the art-imitates-life equation been turned on its head? Has the land of cheese, canals, bicycles and windmills become the harbinger of a brave new world in which the disaffected seek to cash in their tickets of leave at the friendly neighbourhood Suicide Parlor? In the immediate aftermath of the international media coverage of his case, Dr. Chabot received forty telephone calls and letters from outside the Netherlands soliciting his aid to commit suicide. He gently turned them all down, suggesting that they seek counselling for their distress. He continues to insist that he is not "the psychiatrist of last resort," but he does not disavow his role in the case that has brought him such notoriety. In his twenty-five years of practice he had never experienced a patient as driven as Hilly Bosscher was to end her life. As he confided in his case notes, "I cannot behave as if I have no more to do with her now that the help to live which I offered her has failed."

What, finally, is one to make of the desperate pleas for death in the five cases profiled in this article? In a sense, there is indeed logic that leads down the road from the case of a ninety-five year old tormented by multi-organ system failure to a twentyfive year old tormented by a longstanding eating disorder to a fifty year old tormented by personal tragedy but with an intact body and no psychiatric history. As the renowned American jurist, Oliver Wendell Holmes, once observed: "The art of civilization is the act of drawing lines." ${ }^{159}$ Where then does one draw the line? Whose intolerable and irremediable torment qualifies for euthanasia and whose does not? As Eugene Sutorius reminds us, it is the twin pillars of autonomy and beneficence that provide the medical-ethical grounding to the Dutch euthanasia policy. At the very least, the idea of beneficence suggests an act of mercy or kindness - an act designed to mitigate harm or suffering. If we are prepared to accept euthanasia in principle, we must then ask: for what kind(s) of distress will its merciful release be offered?

There is, of course, physical pain - unrelenting, unbearable, and never-ending. But surely we cannot stop there. Euthanasia cannot logically be restricted to pain cases because not only would we then exclude other forms of physical discomfort (e.g. nausea, vomiting, dizziness, diarrhoea, itching) but also the emotional, spiritual and psychological suffering that can wreak havoc upon its victims. After all, any health caregiver can recount cases of patients who were not racked by sheer physical pain but who were nonetheless entrapped by horrific suffering. What counts, then, is that the patient requesting euthanasia is overwhelmed by irremediable misery and torment. In that sense it is pointless to assign weights to its physical and nonphysical components (assuming, of course, the absence of treatment options to mitigate the patient's distress).

Moreover, we cannot logically restrict euthanasia to the terminally ill - to a patient whose torment is by definition marked by a relatively limited time duration. Consider, for example, Dr. Admiraal's patient, Karin L., who faced the prospect of interminable 
anguish from the relentless course of the multiple sclerosis that had caused her to long for death. How could we oblige her to live while granting euthanasia to the patient facing a shorter term prospect of unremitting suffering ${ }^{60}$ The simple answer is that we cannot, lest we betray our commitment to the principle of beneficence.

The Dutch medico-legal criteria accordingly stipulate that the patient must be afflicted with unbearable and intractable pain and/or suffering, but that the patient need not be in the "terminal phase." It is pertinent to note that Dutch studies have indicated that far more than pain, it is suffering (referred to by patients as "loss of dignity" or "unworthy dying") that impels requests for euthanasia. ${ }^{61}$

In any case, if it can be suffering (not simply pain) and if the patient need not be terminal, why then must there be a somatic basis to the complaint in order for the aggrieved patient to qualify for euthanasia? As we have seen, the tormented patients of Drs. Kors, Duintjer and Chabot bear stark witness to the reality of egregious suffering that does not flow from physiological disease. Who can say that their suffering was of lesser magnitude than that undergone by the patients of Drs. Schoonheim and Admiraal? All that one can say is that all five patients experienced life as a living hell. All were convinced that death offered the only release and all their physicians reluctantly came to the same conclusion.

Although the three non-somatic cases mark a new direction in the euthanasia policy of the Netherlands, it is only the Chabot case that has riveted the attention of the Dutch public as well as attracting attention abroad. We suggest that the widespread public interest is partly accounted for by the morbid fascination of a suicide that has all the trappings of Hollywood melodrama: the house bedecked with flowers, the patient choosing to die on her deceased son's bed, her best friend sitting by her side and stroking her face and hair, the compassionate psychiatrist handing her the hemlock as he pleads with her to change her mind, her gentle insistence upon seeing it through, and last but not least her slipping away to the soundtrack of a Bach flute sonata. It is not to make light of the torment that afflicted the patient to suggest that, if the case had

One who would restrict euthanasia to the terminally ill might respond that, no matter how disabled, a nonterminal patient can enforce her will to die by ceasing to ingest food and fluids. Moreover, the more debilitated the patient, the quicker the death. Yet, even so, its early stages would not be pleasant. In any event, such manner of dying hardly fits the literal meaning of euthanasia (the word is derived from the Greek for an easy, painless death). It is arguable that a euthanasia law that would leave only that option for a patient such as Karin L. would make a mockery of its professed commitment to beneficence. And what of the anorexic patient, Maria S.? It is true that instead of involving Dr. Kors, she could have killed herself by spurning food and fluids. But because her metabolism had slowed down to function on minimal nutrition, her dying would have been prolonged and distressing. All this is not to deny, however, that for some elderly and near death patients, the decision to refuse food and fluids can lead to a relatively easy and painless death. 
happened a half century ago, a film producer would have seen the role of Hilly Bosscher as tailor-made for Greta Garbo. ${ }^{62}$

Beyond the melodrama, however, is the haunting spectre of the brave new world sketched by Kurt Vonnegut, a world of state-sponsored suicide for citizens buffeted by the loss of loved ones and other misfortunes. There is a sense in which the plight of Hilly Bosscher stands apart from the "psychiatric suffering" cases of Maria S. and Martha N. Given that the concept of mental disorder fits within the medical model of illness and disease, it is arguable that mentally competent psychiatric patients should not be excluded from eligibility for euthanasia. ${ }^{63}$

In contrast, the case of Hilly Bosscher falls outside the traditional medical model, notwithstanding her involvement with a physician. There is, we suggest, a fundamental sense in which their relationship was markedly different from that of Drs. Kors and Duintjer and their patients. Dr. Chabot was not treating her for a psychiatric disorder, and in her own mind she never assumed the role of patient because she had not come to him to be treated for an affliction. His professional role was that of healer, but her only reason for seeing him was that he was the gatekeeper to a quick and painless death. Although like any "normal" person she had her fair share of neurotic traits, she was not the long drawn-out victim of psychiatric disorder. She had found life's fulfilment as a parent, and the loss of her children had rendered that life meaningless. In that sense, she was not a patient but rather a person who had made the existential choice that life had nothing more to offer her. She knew full well that her tragic situation was not unique and that sole family survivors of genocidal conflict and natural disaster have found the inner strength to rebuild their lives. But that long hard road was not for her, and who amongst us can say with inner conviction that we would still retain the will to live if the cruel hand of fate were to deal us a hand as grim as hers?

To the ancient Greeks, the death of a loved one counted as a natural and rational reason for suicide. (According to legend, when Leander, the lover of Hero, the priestess of Aphrodite at Sestos, drowned whilst swimming to visit her, Hero threw herself into the sea when his body washed ashore. ${ }^{64}$ ) One may deplore that philosophy, but the point is that Hilly Bosscher's case does not belong to the discipline of medicine nor its sub-specialty, psychiatry. She had struggled with the question of the meaning of life, and her answer was that for her, life no longer had meaning. Admittedly, that was the question faced by all five patients in our case studies, yet in her case alone was the suffering unrelated to physical and/or mental disorder.

The great Swedish-born film star of Hollywood fame, Garbo starred in a number of classic melodramatic roles in the 1920s and 1930s. She retired at the height of her fame, saying "I want to be alone," and became a world-famous recluse.

The most noted dissenter from this viewpoint is the American psychiatrist, Thomas Szasz, whose most recent book, Cruel Compassion, is shortly noted (infra note 70). Szasz has devoted a career to attacking the incorporation of mental disorder within the medical model. Needless to say, that issue is beyond the purview of this article.

See J. Choron, Suicide (New York: Charles Scribner's Sons, 1972) at 64. 
Euthanasia is, of course, not simply a medical matter. If it were, the K.N.M.G. would not have turned to ethicists and theologians for counsel when struggling with their position papers on the subject. But to reiterate, the case of Hilly Bosscher had nothing whatsoever to do with medicine, however broadly one defines the discipline. Hers was not a case of medical necessity, even though the case was defended and judged under that heading. One cannot even call it a case of psychiatric necessity, albeit that label does fit the Kors and Duintjer cases. It is arguable that on policy grounds the defence of medical necessity should be confined to so-called somatic cases, thereby excluding our three physician-assisted suicide cases from its coverage. Beyond that is the public policy claim that euthanasia should be restricted to the terminally ill. The "who qualifies" question is a key component of the euthanasia debate but is beyond the scope of this article.

Indeed, one might ponder the long-term effects upon the medical profession were it to become the vehicle for ending the lives of the Hilly Bosschers of this world. In this connection, consider that in American case law involving mentally competent patients who seek the termination of life-prolonging treatment, the courts have engaged in a balancing act. On the one hand, the patient's "right to die" finds support in the constitutional rights to privacy and liberty (under the 14th Amendment) as well as the common law right to self-determination. On the other hand, case law has juxtaposed four competing and legitimate state interests that must be weighed against the patient's claim: the state's role in preserving life, preventing suicide, protecting innocent third parties and preserving the integrity of the medical profession. The courts are thus obliged to determine in the particular case whether any of the four state interests overcomes the patient's right to be rid of the medical technology prolonging his life. As the reported cases indicate, the right of mentally competent patients to refuse lifeprolonging treatment invariably trumps the four state interests. ${ }^{65}$

Thus, the courts have consistently held that the integrity of the medical profession is not compromised by compliance with the wishes of a mentally competent patient for the termination of artificial life-support. Of course, it is a different matter whether any of the four competing state interests, including the integrity of the medical profession, would be compromised by the claimed right of a patient afflicted with somatic disease (whether terminal or not) to physician-assisted euthanasia. Yet, even if the courts were to endorse such a right, that would still leave unanswered the question whether the integrity of the profession would be compromised by its involvement in the kind of case that confronted Dr. Chabot.

Eugene Sutorius would answer, "No." His position is that the litmus test is unbearable affliction that cannot be relieved, and that it matters not whether its origin lies in the realm of the physical, psychological, spiritual or existential. ${ }^{66} \mathrm{~A}$ euthanasia

R.F. Wier, Abating Treatment with Critically III Patients (New York: Oxford University Press, 1989) at 93. sense that the person has come to terms with her place in the world and has defined her existence as no longer worth preserving. In that sense, all five cases canvassed in this article are describable 
policy reflects a commitment to the bio-ethical principles of autonomy and beneficence. Thus, what counts is that the patient is mentally competent, that euthanasia offers the only release from her wretched existence, and that the physician holds the key to effect that release. He thus sees euthanasia as a patient-centred policy with a legitimate place in the package of "final care" that is afforded to the grievously afflicted.

What about cases of anticipatory suffering as reported in the literature on suicide cases prompted by the desire to escape the ravages of ageing and disease by a quick and painless death before the inevitable downward course? One such example is that of Karl Marx's son-in-law, Paul Lafargue. Lafargue was a physician who carried out a longtime promise to kill himself by the age of seventy. He did so by giving himself an injection of hydrocyanic acid, leaving behind a suicide note explaining why:

Sound of mind and body, I am killing myself before pitiless old age, which gradually deprives me of the pleasures and joys of existence and saps my physical and intellectual forces, will paralyze my energy, break my will power, and turn me into a burden to myself and others. ${ }^{67}$

Sutorius was presented with two hypothetical cases of anticipatory suffering. One was that of an HIV-infected patient who asks his physician to help him commit suicide. Although the patient is not suffering in the here-and-now, he sees no reason to wait until his body is overwhelmed by the disease. ${ }^{68}$ The other case was that of a patient just turned eighty years old who echoes the philosophy of Dr. Lafargue but who has no access to lethal drugs. As she calmly explains her request for assisted suicide to her physician, "All in all, I'm in pretty good form for someone my age, but I'm gradually beginning to slow down. Now is the time to end it; I have had a good run at four score years. So why not now, before I feel the onslaughts of time - nature's way of telling us that we weren't meant to live forever? I've settled all my business and this is as good a time as any to wrap it all up."

as existential suicides. However, in Sutorius's view, it is the Chabot case that uniquely captures the essence of an existential decision in its rawest form because there was no somatic or psychiatric history to explain Hilly Bosscher's suffering. He believes that it is truly an exceptional case which does not send the message that Dutch physicians have been assigned the role of complying with requests for assisted suicide by those who are "otherwise healthy" (i.e. no somatic or psychiatric history) but nonetheless wretchedly unhappy. See Choron, supra note 64 at 100.

This hypothetical was inspired by a "real" case as depicted in a documentary film, An Appointment With Death, which profiles a number of Dutch euthanasia cases. The particular segment involves an HIV-infected artist who asks his physician to help him commit suicide because he is determined to avoid an AIDS-ravaged death. He had watched a friend die of AIDS and there was no way that he was going to share that fate. Thus, what prompted his request was not current, but rather, anticipated suffering. The film takes its title from a scene in which the man takes out his appointment book and arranges a particular date (which he says has symbolic meaning for him) for the physician to attend at his apartment and send him on his way. And that is what happens. Since this was not a case of unbearable and irremediable suffering, the physician did not act under circumstances of medical necessity as required by the euthanasia guidelines. The documentary was written and directed by Canadian film maker John Zaritsky. 
Sutorius responded that neither case was a fit subject for physician-assisted suicide, and the reason is that the euthanasia pillars of autonomy and beneficence are interdependent and therefore do not stand alone. It is not enough that the patient chooses to die; that choice must be coupled with suffering of such magnitude as to compromise the patient's existence. Although there are admittedly no objective criteria that can measure pain and suffering, the point is that the beneficence component of a medically grounded euthanasia policy hinges upon the relief of the patient's current suffering. The state cannot legalize euthanasia to accommodate the quest to avoid the travails that mark the very nature of human existence. Autonomy is not enough. Suffering in the here-and-now is the benchmark that triggers the commitment to beneficence and state-sanctioned euthanasia cannot get along without it. Anything less is tantamount to the sanctioning of euthanasia on demand, a morally unacceptable policy that to Sutorius conjures up visions of the pleasant hostesses who staff Kurt Vonnegut's Suicide Parlors.

Furthermore, as Sutorius added, anticipatory suffering is antithetical to the very nature of the defence of medical necessity, which invokes an urgent and desperate situation in which the physician is compelled to spare his patient from further agony. As he sees it, it is the Chabot case that defines the outermost limits of the autonomy/beneficence equation. Finally, although he was not prepared to quarrel with the reasoning of the two hypothetical patients, he was led to conclude that they must seek their own way without medical help.

It is the Chabot case, we suggest, that calls to mind an oft-quoted dictum by the renowned philosopher John Rawls: that it is one thing to justify an act but quite another to justify a general policy. ${ }^{69}$ In other words, notwithstanding the compelling evidence that Dr. Chabot did the right thing by helping end the nightmare of Hilly Bosscher's existence, it is arguable that that kind of case goes beyond the limits of permissible euthanasia (assuming of course one's acceptance of euthanasia in principle).

Is the Chabot case indeed beyond the pale? Resolving the matter obliges one to address fundamental questions on the vicissitudes of human existence. And beyond that, one must consider the nature of individual responsibility, suffering, suicide, the roles of law and medicine in the pursuit of patient autonomy, and the role of the state vis-a$v i s$ the individual.

At this juncture we would simply call the reader's attention to a recently published monograph, Cruel Compassion, ${ }^{70}$ in which psychiatrist Thomas Szasz takes on the issue of physician-assisted suicide. Szasz is a longtime critic of the role of physicians (especially psychiatrists) as instruments of social control, and in Cruel Compassion he expresses his aversion to the extension of their power into the realm of assisted suicide. As a longtime libertarian, Szasz is not opposed to the legalization of assisted suicide; his bugbear is physician-assisted suicide. In other words, his objection is to the role of physicians as the keepers of the keys, as the power brokers who would decide which enforced, and justifying a particular action which falls under these rules..." (J. Rawls, "Two Concepts of Rules" (1955) 64 Philosophical Rev. 3 at 5). 
requests merited their co-operation. In his writings over three decades, Szasz has heaped invective upon the human tendency to solve moral problems by medicalizing them. In Cruel Compassion he questions the medical role in what is essentially a moral enterprise: the choice to embrace suicide because one has concluded that life is no longer worth living. Although a critique of Szasz's position is beyond the scope of this article, we readily grant the profound implications of the physician's gatekeeper role in the Chabot/Bosscher case, in which the suicide was not framed against the backdrop of a medical or psychiatric history. ${ }^{71}$ The job description for that gatekeeper's role requires the wisdom of Solomon, and even the wisest and most caring physician must be hard pressed to meet its challenge. It is no doubt trite to say that it will be a formidable task to come to grips with the issues raised by the case of Hilly Bosscher and Dr. Boudewijn Chabot.

\section{CONCLUSION}

In order to understand why the Dutch have tolerated the practice of euthanasia, one must consider the very nature of the society from which that policy has sprung. As explained by law professor John Griffiths, a transplanted American who has taught law at the University of Groningen since 1978, the medico-legal regulation of euthanasia is the product of a four centuries' Dutch tradition of tolerance and respect for autonomy that finds expression in other areas of social programming as well. ${ }^{72}$ Consider, for example, the Dutch approach to so-called consensual crimes, which have traditionally been criminalized elsewhere, particularly in common law jurisdictions. In the Netherlands: pornography, prostitution and the sale of marijuana are regulated but not prohibited; consumers of hard drugs are not prosecuted for possession; abortions are legally available; and Dutch society is known for its open tolerance of homosexuals.

Aside from tolerance toward diversity and respect for autonomy, another backdrop to the euthanasia policy of the Netherlands is the Dutch cultural characteristic of pragmatism - if the consensual activity in question cannot be suppressed, then better it should be brought above ground and regulated. In short, there is a sense in which the medical practice of euthanasia is part and parcel of Dutch policy approaches that are invariably commented upon by outside observers: the carefully demarcated red light districts; the open sale of pornography; and not only coffee shops selling marijuana but also hydroponic stores selling the equipment for growing it. To its critics, whether the issue is euthanasia, abortion or the other traditionally criminalized consensual crimes, the Netherlands stands indicted as a permissive society. Most of the Dutch don't see it that way. They would say about euthanasia what they would say about other consensual activities that all too often have been assailed by moral crusaders: it is better to react to human diversity with tolerance than intolerance; pragmatism is better than the no-win law enforcement war against consensual crimes; and respecting autonomy is better than trying to force people to refrain from conduct that can directly harm only themselves. 
Finally, it is pertinent to note that a recurrent theme expressed by Dutch commentators is that their approach to euthanasia is not for export. They are not suggesting that euthanasia is an appropriate policy only in their country, but rather that its right to moral standing elsewhere is tied to the nature of the particular society's culture and health care system. In the Netherlands, a comprehensive national health insurance scheme provides broad and extensive coverage. Thus, whatever one's socioeconomic status, all are entitled to appropriate medical care. That kind of a health care system is regarded by the Dutch as the cornerstone of their euthanasia policy. The policy is set within that framework, but beyond that (as just explained) one cannot understand the policy unless it is viewed from within the broader societal context. In other words, euthanasia in the Netherlands has a distinctly Dutch stamp to it.

It is in this sense that the defence of medical necessity has a socio-political component. In Dutch law, euthanasia is acceptable only as the medical measure of last resort: when there are no reasonably available alternative means to ease the patient's intolerable plight. It follows that the integrity of the defence would be compromised in a society that did not offer the protection of a national health insurance scheme providing state-of-the-art medical and palliative care services. If a patient pleads for euthanasia to avoid becoming a financial burden to her family or because of inadequate pain control measures, compliance with her plea makes a mockery of the notion of last resort. $^{73}$

It goes without saying that the policy of "ethical suicide" as conjured up by Kurt Vonnegut can become the cost-saving vehicle for a society lacking programmes for the welfare of its afflicted citizens, whether out of malice or the lack of resources to do the job. After all, the budget for the Ethical Suicide Service (requiring parlors, drugs, hostesses and advertising) would consume a pittance of what it would cost to fund the health care resources needed to ensure that euthanasia is truly the medical measure of last resort.

In such a world, there would still be a "necessity" component to the practice of euthanasia. But it would no longer be a patient-oriented policy whose spirit is captured by the literal meaning of euthanasia, defined by the Oxford dictionary as an "[t]he action of inducing a gentle and easy death ... [especially for] ... those suffering from incurable and extremely painful diseases." ${ }^{74}$ Rather, it would stamp a state-sanctioned policy regretfully implemented as but one of many necessary budget-trimming measures in a time of fiscal restraint. And if the surgery is not radical enough, the E.S.S. could always market a Do It Yourself Home Suicide Kit for a nominal fee, complete with a money-back-if-no-full-satisfaction guarantee. second edition of B. Sneiderman, J. Irvine \& P. Osborne, Canadian Medical Law: An Introduction for Physicians, Nurses, and Other Healih Care Professionals (scheduled for publication in January 1996 by Carswell). The discussion of the Dutch situation is in chapter 25 and was co-authored by the writers of this article.

74 The Oxford English Dictionary, vol. 5, 2d ed. (Oxford: Oxford University Press, 1989) at 444. 